\title{
Cloud-to-Ground Lightning Flash Density and Thunderstorm Day Distributions over the Contiguous United States Derived from NLDN Measurements: 1993-2018
}

\author{
THOMAS L. KOEHLER \\ Department of Economics and Geosciences, U.S. Air Force Academy, Colorado Springs, Colorado
}

(Manuscript received 27 June 2019, in final form 18 September 2019)

\begin{abstract}
This study employs cloud-to-ground (CG) lightning flash data from the U.S. National Lightning Detection Network (NLDN) to examine temporal and spatial distributions of lightning flash and thunderstorm day (TD) occurrences over the contiguous United States from 1993 to 2018. TD distributions are estimated from NLDN CG flashes using 4 thunder audibility approximations: 5 and 10 nautical mile $(\mathrm{n} \mathrm{mi} ; 1 \mathrm{n} \mathrm{mi}=1.852 \mathrm{~km})$ audibility ranges, and minima of 1 and 2 flashes within the audibility range. The 26-yr period examined is longer than previous studies using NLDN data, and the TD results can be compared directly to climatologies derived from surface weather observations dating back to the late 1890s. Results based on the abundant NLDN data avoid limitations introduced by the coarse horizontal resolution of surface observations inherent in pre-NLDN TD climatologies. Annual mean flash density and annual and monthly mean TD distributions are derived from almost 568 million NLDN CG flashes. A mean annual maximum of more than 16 flashes $\mathrm{km}^{-2}$ is found near Tampa, Florida. The mean annual TD maximum of 113 days (from at least 2 flashes within $10 \mathrm{n} \mathrm{mi}$ ) occurs in southern Florida. Regions exceeding 70 TDs are found from eastern Texas eastward into Florida, and over the southern Rocky Mountains. Large positive deviations from the mean number of TDs extend from Texas northwestward into Colorado during 2003-07, followed by large negative deviations over the same region during 2008-12. Both deviation patterns are similar to expected summertime precipitation anomaly patterns over the United States during El Niño and La Niña years, respectively.
\end{abstract}

\section{Introduction}

Thunderstorms are awe-inspiring phenomena due not only to fantastic lightning displays seen from afar on a summer night, but also to their destructive potential. The cloud-to-ground (CG) lightning flashes themselves pose risks to lives and property. Weather-related fatality data compiled by the National Weather Service since 1940 (NWS 2018) show the number of lightning-related deaths in the United States decreased from a high of 432 in 1943 to a low of 16 in 2017 due to several factors, including radar tracking of thunderstorms and better lightning safety education. Koshak et al. (2015) note decreases in the number of lightning fatalities, injuries and lightning-induced wildfires, but increases in damage to crops and property across the United States from the first to second half of their 2003-12 study period. Severe thunderstorms produce large hail, damaging straight-line winds, and/or tornadoes. Thunderstorms

Corresponding author: Dr. Thomas Koehler, thomas.koehler@ afacademy.af.edu form the building blocks for larger mesoscale convective systems, such as squall lines and mesoscale convective complexes. Intense and persistent precipitation from thunderstorms and other convective systems can produce floods and flash floods. Thunderstorms also provide beneficial rainfall over the grain-producing regions of the Great Plains where more than $50 \%$ of the precipitation comes from thunderstorms (Changnon 2001a). As Aich et al. (2018) note, the relationships among lightning, thunderstorms, and other climaterelated variables have resulted in lightning becoming an essential climate variable.

Thunderstorm occurrence has been systematically documented over the contiguous United States (CONUS) since the inception of weather observing by the Army Signal Corps in the 1870s (Alexander 1915). Since 1884, the criteria for determining thunderstorm occurrence in official surface weather observations have included thunder being heard by weather observers. By international agreement, a thunderstorm day (TD) was defined as a local calendar day in which thunder was heard (WMO 1953). In the United States, the criteria 
for reporting a thunderstorm by surface weather observers have evolved over the years. The Federal Meteorological Handbook No. 1 (FMH-1) (U. S. Department of Commerce 2017) states that a thunderstorm should be reported when one of these criteria are met:

1) thunder is heard,

2) lightning is observed at the station when the local noise level is sufficient to prevent hearing thunder, or

3) lightning is detected by an automated sensor.

The third criterion was added to the FMH-1 in 1998 after lightning detection measurements were incorporated into Automated Surface Observing System (ASOS) observations of thunderstorms (NWS 1998).

Several factors introduce uncertainty into reporting thunderstorms in human or automated surface observations, especially when constructing a thunderstorm climatology over a long time period. The observing location might change. This was a frequent occurrence during the first half of the twentieth century when many observing sites were moved from midtown locations to outlying airports. Data collection might increase from part day to 24 hours. This was especially true in the 1990s and 2000s when ASOSs were installed at sites with part-day human observing. The definition of what constitutes a thunderstorm for surface reports has also evolved. For example, the addition of observing lightning as a possible thunderstorm reporting criterion went into effect when observing sites were moved to noisier airports. As noted by Reap and Orville (1990) the 1975 version of FMH-1 mandated reporting a thunderstorm when hail was observed, a requirement that was later removed. Finally, temporal variations in the acoustical properties of the atmosphere can lead to variations in the audibility of thunder at an observing site (Changnon 2001b).

As noted by Orville (2008), the remote sensing of CG flashes with acceptable precision only became feasible in the late 1970s after the invention of wide-band lightning direction finders (Krider et al. 1976), and development of the ability to locate lightning flashes using measurements from multiple sensors. By the late 1980s, lightning detection and data dissemination had matured to the point that several regional lightning detection networks were operating over the CONUS. These networks were consolidated into the U.S. National Lightning Detection Network (NLDN) in 1989 (Orville 2008). The network records primarily CG flashes, and its CG flash detection efficiency (DE) has improved from less than $70 \%$ in 1989 (Orville 1991) to greater than $95 \%$ since 2013 (Murphy and Nag 2015).
Prior to the development of the NLDN, climatologies of thunderstorm activity were based on surface weather reports that depended on observers hearing thunder at fixed surface stations. The first such climatology for the United States was produced by W. H. Alexander, who constructed a map of the total number of days with thunderstorms from stations in the CONUS and southern Canada for 1904-13 (Alexander 1915). Court and Griffiths (1986) provide a summary of numerous TD climatologies compiled from 1913 to 1974, and present one of their own for the 25 years, 1951-75, compiled from 205 stations. Changnon (2003) provides a comprehensive study of TD variations over the CONUS. His data include 841 locations for the 100 years, 1896-1995. His map (Fig. 1), displays a maximum area with values exceeding 70 TDs over Florida through the Louisiana Gulf Coast. Other local maxima with values exceeding 50 TDs are found over the central United States, and in parts of Colorado, New Mexico, and Arizona. Other studies, including Changery (1981), Easterling and Robinson (1985), and Changnon (1988), provide in-depth information about the annual number of thunderstorms, total thunderstorm minutes, and average thunderstorm durations, as well as diurnal variations in thunderstorm activity using a specialized thunderstorm duration dataset for the period 1948-77.

Since the inception of the NLDN, the focus of documenting thunderstorm activity has shifted from TD analyses derived from surface observations to flash density analyses derived from the frequency of CG flashes measured by the network. Multiyear studies using NLDN data include 10-yr studies from Orville and Huffines (2001) for 1989-98 and Holle et al. (2016) for 2005-14. The latter paper also provides an overview of other NLDN-based flash density studies. Flash density distributions are particularly relevant to lightning safety, because a person's chance of being struck by lightning at a given location increases with increasing flash density (Roeder et al. 2015). Numerous studies have employed lightning-location system (LLS) measurements to examine both flash density distributions and the number of hours or days with lightning activity for several different regions. Three of those studies specifically employed NLDN CG flash data over the entire CONUS: Huffines and Orville (1999) produced a mean annual flash hour map for 1989-96, Zajac and Rutledge (2001) included a CG lightning days per year map for 1995-99, and Mäkelä et al. (2011) created a map depicting the mean annual number of TDs for 2003-07. All three studies used similarly sized grids (approximately $20 \mathrm{~km} \times 20 \mathrm{~km}$ ), and the authors noted that this grid spacing corresponded roughly to the maximum distance that thunder would be audible from a given lightning flash. 


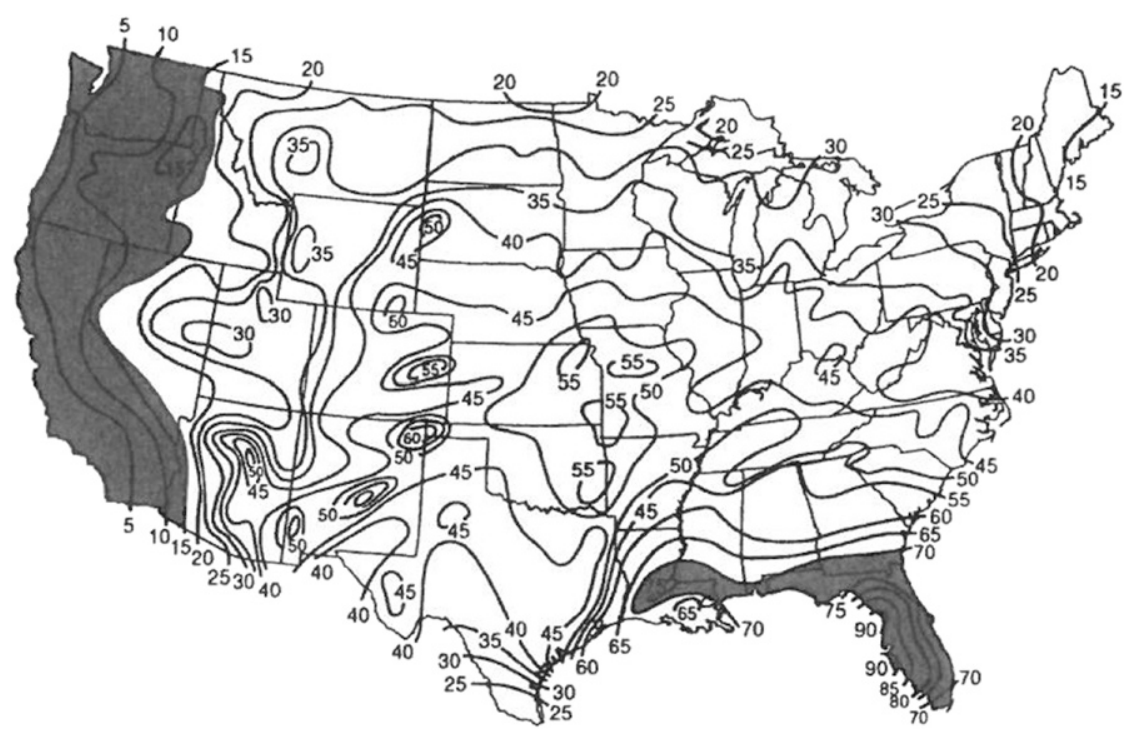

FIG. 1. Annual mean number of TDs in the 100-yr period, 1896-1995, from Changnon (2003). Regions with 15 or fewer, and 70 or greater TDs are shaded. (Reprinted by permission of the publisher, Taylor and Francis Ltd, http://www.tandfonline.com.)

These results could then be compared directly to thunderstorm hour and day climatologies derived from surface weather observations.

The research described in this paper employs a geographic information system (GIS) approach to approximate where thunder would be heard from NLDN CG flash observations. The resulting TD distributions are used to construct a 26-yr TD climatology for 1993-2018 across the CONUS. Subsequent sections describe the approach used for approximating TDs from CG flash data, the data processing methodology, and the 26-yr results and their interannual variation. The research presented here provides a refined yet simple approach to determining TDs from NLDN flash data, examines a longer period than previous NLDN-based studies, and unlike flash density maps, allows direct comparisons to more than a century of TD climatologies derived from surface weather observations.

\section{Methodology}

This section describes the details of how flash density and TD maps were constructed from the CG lightning flash data archived at the NCEI. The data are stored in daily files based on coordinated universal time (UTC) with time specified to the nearest millisecond, and location given in geographic (latitude, longitude) coordinates to the nearest 0.001 of a degree.

\section{a. Definition of a thunderstorm day}

A day is typically defined from midnight (0000:00) to just before the next midnight (2359:59.999) with noon
(1200:00) the midpoint of the day. In the CONUS, 0000 UTC varies between 1900 on the East Coast and 1600 on the West Coast in local standard time. Since one of the driving forces for thunderstorms is solar insolation, it makes sense to set noon as the time when the sun is directly overhead at any location in the sample. One approximation is to use local mean solar time (LMT) as done by Zajac and Rutledge (2001) and Holle (2014). The adjustment from UTC to LMT is a function of only longitude as shown in (1):

$$
\text { Hour }_{\text {LMT }}=\text { Hour }_{\text {UTC }}+\frac{\text { Longitude }}{15^{\circ}} \text {. }
$$

Here longitude is measured positive eastward from the Greenwich meridian, so longitudes in the CONUS are negative. A more accurate time system is apparent solar time (AST). The adjustment of LMT to AST includes the equation of time (EqT), which accounts for seasonal variations in the eccentricity of Earth's orbit and the obliquity, or tilt, of Earth's axis of rotation with the ecliptic plane. Adding this adjustment to (1) yields (2):

$$
\text { Hour }_{\text {LMT }}=\operatorname{Hour}_{\mathrm{UTC}}+\frac{\text { Longitude }}{15^{\circ}}+\operatorname{Hour}_{\mathrm{EqT}} .
$$

See USNO (2012) for the equation of time approximation used in this study.

In practical terms, lightning flash data from two days (Day 1 and Day 2) in UTC are needed to produce one daily AST file. EqT values at 0000 and 1200 UTC for both days were computed first. Then, the AST of a 
lightning flash was computed using (2) by linearly interpolating between the four EqT values to the UTC of the observation. If the result fell in Day 1 (AST), it was retained in the Day 1 (AST) NLDN file.

A TD occurs when thunder is heard at any time during the day (AST). Using this definition, a nocturnal thunderstorm that produces lightning on both sides of midnight generates a TD for both dates. In reality, the distance that thunder can be heard from a lightning flash, either CG or intracloud (IC), is dependent on three-dimensional acoustical properties of the atmosphere, local acoustic noise levels, and the presence of buildings or topography that can reflect or block the generated sound waves. Another complication is the horizontal extent of lightning channels that are typically $10 \mathrm{~km}$ in length (MacGorman and Rust 1998) and can be up to $321 \mathrm{~km}$ long (Lang et al. 2017). The simple approach used here is to assume that every location within a circle with a defined distance from a CG flash would hear thunder. The NCEI NLDN lightning data archive only includes CG flashes, so thunder heard by observers generated by IC flashes are not included using this approach. The mean IC/CG ratio over the CONUS as reported by Boccippio et al. (2001) is 2.94, so roughly 3 out of 4 lightning events are IC. A later study by Medici et al. (2017) shows the mean regional IC/CG ratio varies between 1.5 and 6.3. MacGorman et al. (2011) note that $10 \%-20 \%$ of the Great Plains thunderstorm events they studied produced only IC flashes, and thus, no CG flashes. Since the NLDN archive ostensibly only includes CG flashes, the approach applied here should underestimate thunderstorm occurrence.

Audibility studies noted in Changnon (2001b) suggest that the maximum distance thunder can be heard is between 8 and $24 \mathrm{~km}$ from lightning. Thunder audibility radii of 9.3 and $18.5 \mathrm{~km}$ ( 5 and $10 \mathrm{n} \mathrm{mi}$, respectively) are employed in the research for this paper. These radii were chosen to correspond with the radii used for classifying thunderstorm (TS) and thunderstorm in the vicinity (VCTS) reports for ASOS observations at sites where NLDN CG lightning flashes determine the presence of thunderstorms (NWS 1998).

Previous studies estimating thunderstorm day or hour distributions from lightning observations use a wide variety of estimates for thunder audibility. Taszarek et al. (2015) describe a method for evaluating TDs from the Polish PERUN lightning detection network that starts with a $1 \mathrm{~km}$ flash frequency grid for the day, and bases the TD determination on a circular region with a radius of $17.5 \mathrm{~km}$. Mäkelä et al. (2014) also use a $1 \mathrm{~km}$ grid, but with a circle of radius $11.3 \mathrm{~km}$ for their TD determination. Studies over the United States, such as Reap (1986), Zajac and Rutledge (2001), Huffines and Orville (1999), and Mäkelä et al. (2011), use a less refined technique in which the presence of a lightning flash anywhere within a larger grid cell that approximates the area of audible thunder for an hour or a day is then defined as a lightning or thunderstorm hour or day. In general, larger regions used in the thunderstorm hour or day determinations should lead to a greater number of events identified.

Another parameter that varies from study to study is the number of CG flashes within the region of influence of a grid cell needed to trigger designation as a thunderstorm. The ASOS algorithm requires at least two CG flashes within a $15-\mathrm{min}$ period to identify the beginning of a thunderstorm. This decreases the effect of false reports (NWS 1998). Reap (1986), Fosdick and Watson (1995), Clodman and Chisholm (1996), and Taszarek et al. (2015) also require at least two flashes within the audibility range for the $24-\mathrm{h}$ period to identify their equivalent of a TD. López and Holle (1986), Watson and Holle (1996), Huffines and Orville (1999), Zajac and Rutledge (2001), and Mäkelä et al. (2011) require at least one flash. The research presented here employs both one-flash and two-flash minimum thresholds within the audibility range to define a TD, with one-flash minimum TD results expected to exceed those based on a two-flash minimum requirement.

The analysis grid used in this study is defined using the North American equidistant conic projection with $0.5 \mathrm{n} \mathrm{mi} \times 0.5 \mathrm{n} \mathrm{mi}(926 \mathrm{~m} \times 926 \mathrm{~m})$ grid cells. A flash frequency (number of CG flashes) analysis, and four TD analyses (assuming audibility ranges of 5 and $10 \mathrm{n} \mathrm{mi}$, and minima of one and two CG flashes to define a TD) are constructed using the Point Statistics function in the ArcMap program, from the Spatial Analyst extension of ArcGIS (ESRI 2018).

\section{b. Period of study}

NLDN CG lightning data from 1993 to 2018 are employed in this investigation. This 26-yr dataset facilitates examining the interannual variability of thunderstorm activity, especially when compared to the 10 -yr or fewer datasets used in previous NLDNbased studies. One complication of using a long period is that the ability of the network to detect a CG flash improved dramatically during the years of this study. The NLDN underwent upgrades during 1994-95, 200203, 2010-12, and 2013 (Cummins and Murphy 2009, and Koshak et al. 2015), resulting in overall improvements to the accuracy of lightning flash location and the CG flash DE. According to Cummins et al. (1998) the NLDN DE values prior to the 1994-95 upgrade were 


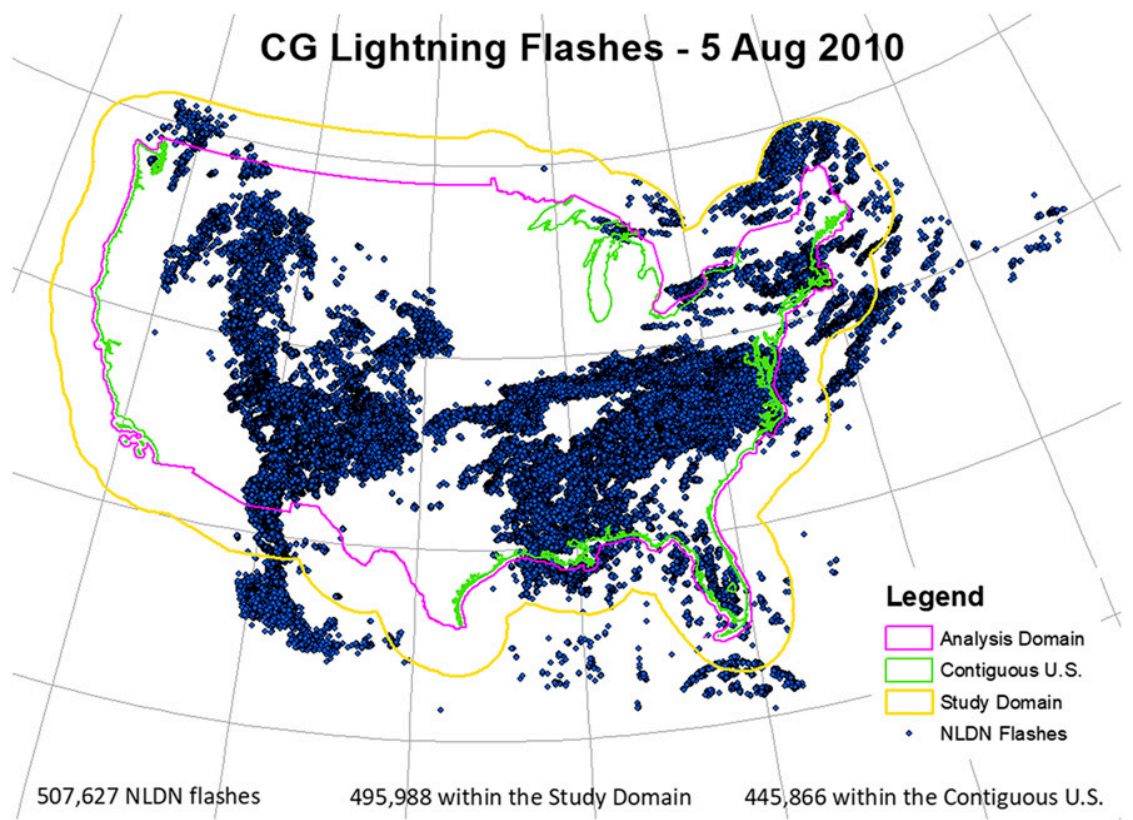

FIG. 2. A map showing the study domain (yellow) outlining the output region used in basic processing, the boundary of the CONUS (green), and the analysis domain (magenta) used to construct the final maps and statistics presented in this paper. The date, 5 Aug 2010, was the most active lightning day within the study domain during the 26 -yr period. The CONUS outline (green) coincides with the analysis domain outline (magenta) along the land borders of the United States with Canada and Mexico, and cannot be seen in this figure because the analysis domain is the top layer displayed.

$65 \%-80 \%$. Medici et al. (2017) quote DE values of $70 \%-90 \%$ after the $1994-95$ upgrade, $90 \%-95 \%$ after the 2002-03 upgrade, and greater than $95 \%$ after the 2013 upgrade, and document a marked improvement in DE in-network variability between the 1994-95 and 2002-03 upgrades. Some of this improvement arose from including Canadian lightning location observations in 1998 when the North American Lightning Detection Network was formed, increasing DE values in U.S. regions bordering Canada (Cummins and Murphy 2009).

\section{c. Study and analysis domains}

The NLDN lightning flashes for 5 August 2010 are used as a backdrop for illustrating the study domain in Fig. 2. The study domain boundary (yellow) is generally $280 \mathrm{~km}(150 \mathrm{n} \mathrm{mi})$ outside the contiguous United States. This generous buffer allows all CG lightning flashes outside the CONUS but within the audibility ranges of 5 and $10 \mathrm{n} \mathrm{mi}$ of points inside the CONUS to be included in the analysis. The analysis domain boundary (magenta) incorporates not only the land regions of the CONUS, but also portions of the Great Lakes and adjoining ocean regions out to about $12 \mathrm{n} \mathrm{mi}$ that include bays, inlets, and waterbodies separating coastal islands from the mainland. This analysis domain is used to clip the study domain gridded analyses to produce the statistics and maps presented in the results section. The diurnal CG flash distribution is derived for land regions of the CONUS (outlined in green).

\section{d. Removal of positive CG flashes with peak currents $\leq 15 \mathrm{kA}$}

Cummins and Murphy (2009) noted that low-current positive flashes in the NLDN dataset are often IC flashes that are mistaken as CG flashes. These flashes were removed from the NLDN data before archival at NCEI for the dates 5 April 2006 through 5 January 2016. To be consistent, similar low-current positive flashes still present in the NCEI archive on days prior to 5 April 2006 and after 5 January 2016 were removed before subsequent data processing commenced.

\section{e. Data processing steps}

All available NLDN daily data files covering the 26 years, 1993-2018, were downloaded from the NCEI lightning data archive. Only 38 days of the possible 9496 were missing, leaving 9458 days to be processed in the following manner: 
Step 1-Convert the UTC daily files to AST daily files Step 2-Remove positive flashes with peak currents $\leq 15 \mathrm{kA}$ during the appropriate days from 1993 to 2006, and from 2016 to 2018.

Step 3-For each day (AST):

A-Remove all lightning flashes occurring outside the study domain

$\mathrm{B}$-Produce five analyses at a grid resolution of $926 \mathrm{~m} \times 926 \mathrm{~m}$ covering the study domain

- flash frequency ( $\mathrm{Fr}$-number of flashes)

- TD using a $5 \mathrm{n}$ mi audible range and a one-flash minimum (T5F1)

- TD using a $10 \mathrm{n}$ mi audible range and a one-flash minimum (T10F1)

- TD using a $5 \mathrm{n}$ mi audible range and a two-flash minimum (T5F2)

- TD using a $10 \mathrm{n}$ mi audible range and a two-flash minimum (T10F2)

$\mathrm{C}$-Determine the hourly number of CG flashes over land regions of the CONUS.

The processing yielded 9421 daily (AST) sets of Fr, T5F1, T10F1, T5F2, and T10F2 analysis grids. Figure 3 shows a close-up of the five analyses over the Mississippi Valley from 5 August 2010, the date for the CG flashes shown in Fig. 2. The Fr analysis grid is shown in Fig. 3a. A maximum of more than $20 \mathrm{CG}$ flashes in a grid cell is found over north-central Mississippi in the southern part of the map. A solitary lightning flash over northeastern Arkansas produced concentric dark blue and light blue TD circles in Fig. $3 b$ with radii of 10 and $5 \mathrm{n} \mathrm{mi}$, respectively. The circles for this solitary lightning flash disappear in the two-flash minimum analyses shown in Fig. $3 c$ because there are no other flashes within the audibility ranges. As expected, the TD regions for both the 5 and $10 \mathrm{n} \mathrm{mi} \mathrm{audibility} \mathrm{ranges} \mathrm{in} \mathrm{the} \mathrm{two-flash}$ minimum results decreased compared to their corresponding one-flash minimum analyses.

The daily grids were summed for each of the 312 months in the 26-yr sample, and the monthly grids were clipped using the analysis domain boundary. The clipped monthly grids were combined to produce the variety of analyses shown in the subsequent sections. All the products shown with the exception of the diurnal lightning flash frequency distribution were derived over the analysis domain.

\section{Lightning flash results}

Almost 568 million CG flashes were detected by the NLDN over the analysis domain during the 26 years of this study, with a mean value of more than 21.8 million flashes per year. Annual lightning frequencies (Fr) are represented by the red line in Fig. 4a. Values for various statistical measures for the Fr annual totals are listed in

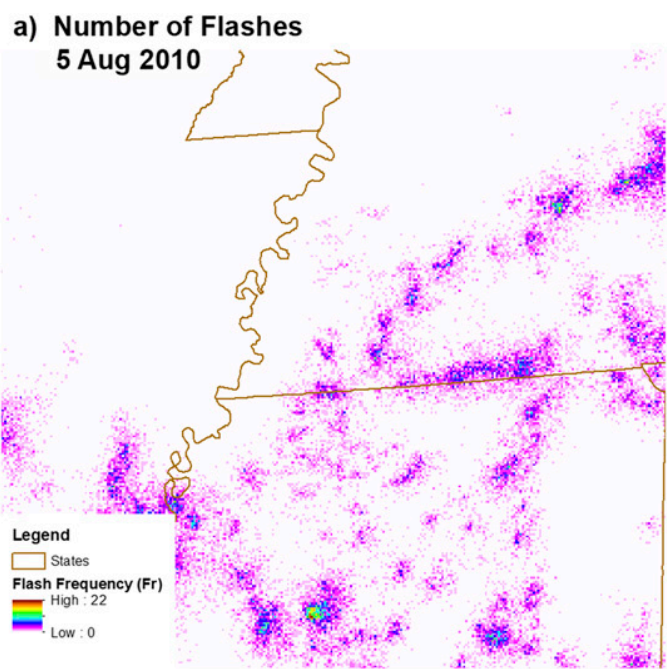

b) Thunderstorm Day (One-Flash Minimum) 5 Aug 2010

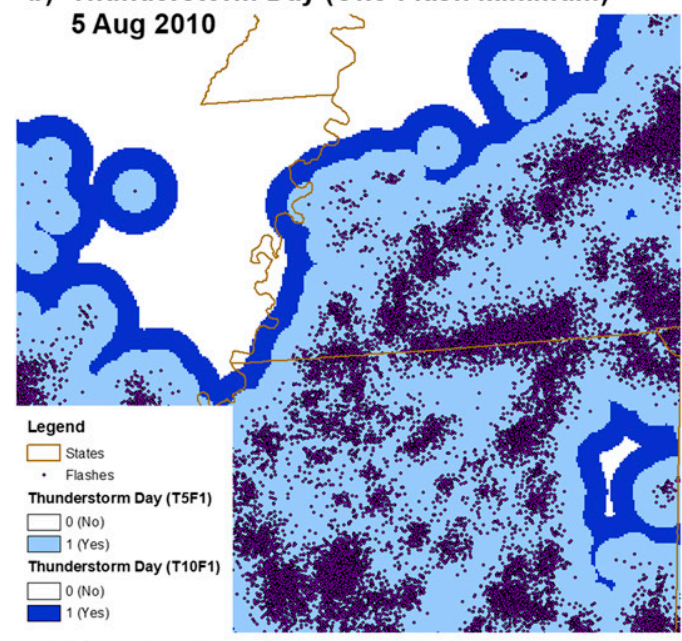

c) Thunderstorm Day (Two-Flash Minimum)

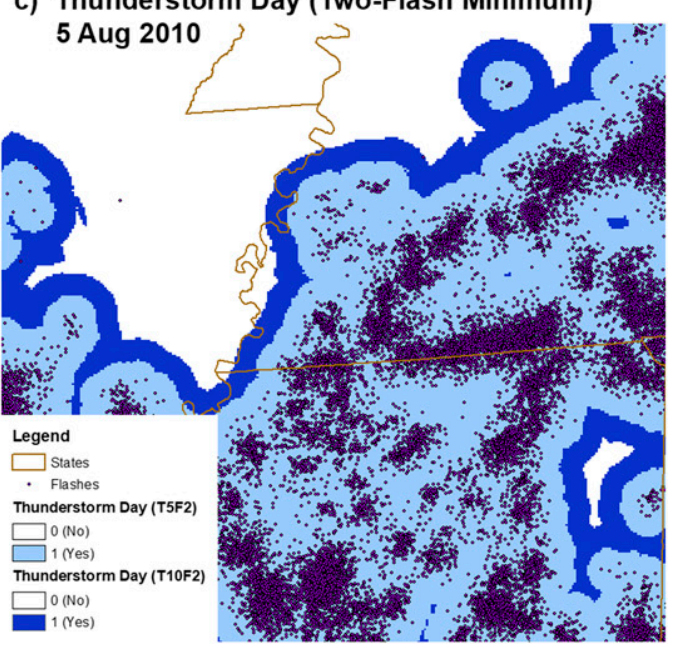

FIG. 3. Examples of 5 Aug 2010 (a) lightning flash frequency and (b),(c) the TD analyses over a portion of the Mississippi Valley. The locations of the individual lightning flashes are included in (b) and (c). A grid cell is assigned a value of 0 (No) if the required number of flashes is not found within the audibility range, and a value of 1 (Yes) if it is. 

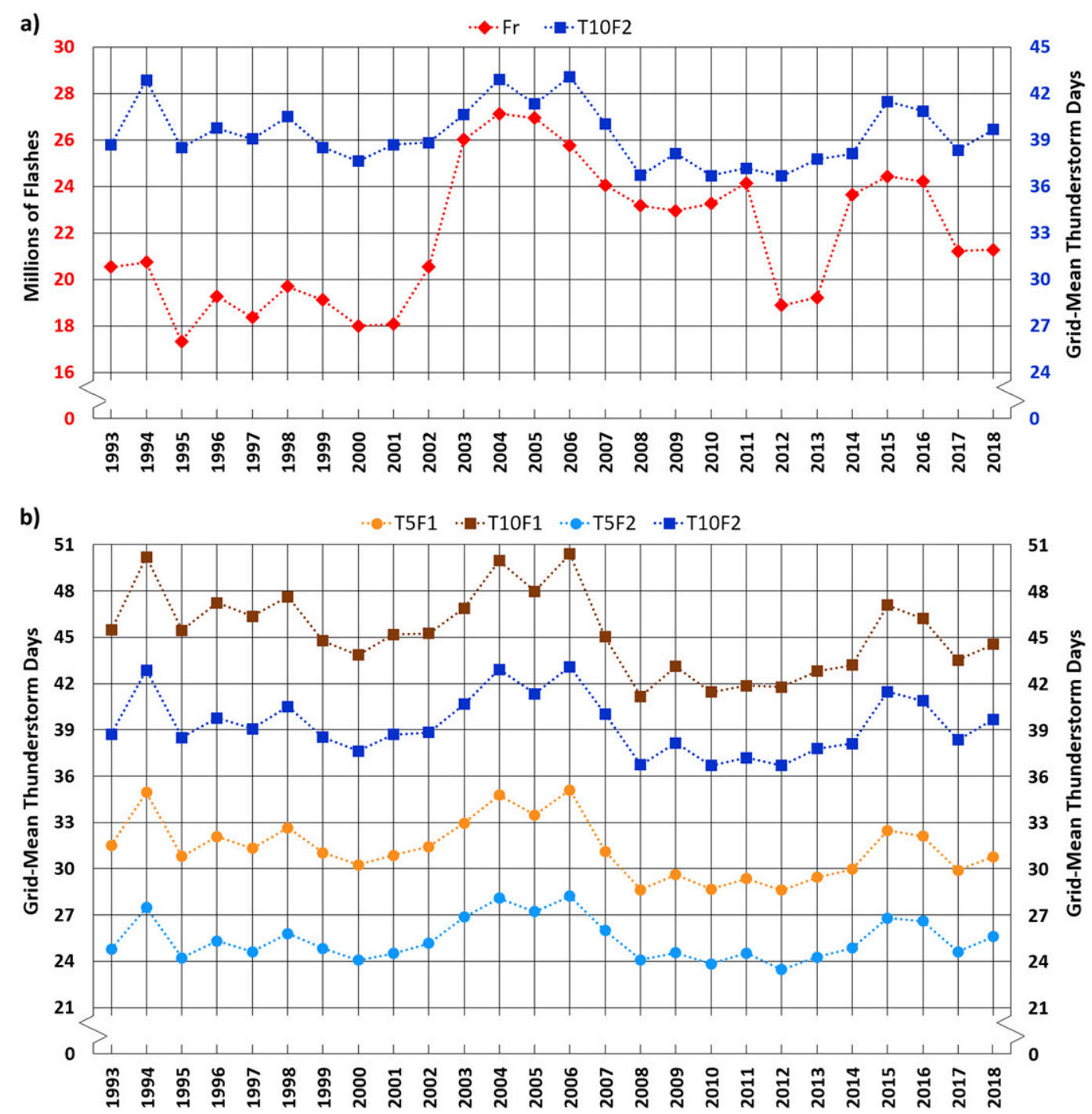

FIG. 4. (a) Annual total number of CG lightning flashes within the CONUS in millions of flashes (red, left vertical axis), and grid-mean number of T10F2 TDs (blue, right vertical axis) for each year of the 26-yr study period, and (b) annual grid-mean TDs for the four audibility alternatives.

the first row of Table 1 . The first nine years of the study, 1993-2001, show Fr totals between 17 and 21 million flashes, followed by an abrupt increase to more than 25 million flashes from 2003 to 2006 . Only four subsequent years, 2007, 2011, 2015, and 2016, exceed 24 million flashes. The abrupt increase in annual CG flashes was due in part to the 2002-03 upgrade, while possible increases due to improvements from the 1994 95, 2010-12, and 2013 upgrades are difficult to differentiate from year-to-year variability.

Mean monthly flash totals (1993-2018) shown in Fig. 5 (red line) are lowest in December (0.13 million flashes) and highest in July (5.38 million flashes). Nearly two-thirds $(65.2 \%)$ of the total number of yearly flashes occur during the summer months of June, July, and August. The shape of this distribution is almost identical to the monthly graph in Holle et al. (2016) for 2005-14.

The hourly distribution of flash frequency depicted in Fig. 6 varies between 0.30 million flashes at 8 and 9 AST and 1.83 million flashes at 15 and 16 AST. The shape of this distribution is quite similar to the 2-h (LMT) graph in Holle (2014) for 2005-12.

The mean annual flash density map averaged over the period of study appears in Fig. 7. The flash counts were collected at a grid resolution of $926 \mathrm{~m} \times 926 \mathrm{~m}$. These counts were summed over $4 \times 4$ subsets of these grid cells to yield counts on a coarser grid with $3704 \mathrm{~m} \times$ $3704 \mathrm{~m}$ resolution. These aggregates were then divided 
TABLE 1. Statistics for the Fr, T5F1, T10F1, T5F2, and T10F2 product grids from the CONUS derived from the 26 yearly values for the period of study (Fig. 4). The coefficient of variation (in percent) is defined as the ratio between the standard deviation and the mean, multiplied by 100 (Brown 1998).

\begin{tabular}{lccccc}
\hline \hline \multicolumn{1}{c}{ Product } & Minimum (yr) & Maximum (yr) & 26-yr mean & Standard deviation & Coefficient of variation \\
\hline Fr grid total (millions of flashes) & $17.3(1995)$ & $27.1(2004)$ & 21.8 & 2.9 & 1.9 \\
T5F1 grid mean (days) & $28.6(2012)$ & $35.1(2006)$ & 31.3 & $5.3 \%$ & $5.9 \%$ \\
T10F1 grid mean (days) & $41.4(2010)$ & $50.4(2006)$ & 45.3 & 2.6 & $5.7 \%$ \\
T5F2 grid mean (days) & $23.5(2012)$ & $28.2(2006)$ & 25.4 & 1.3 & $5.2 \%$ \\
T10F2 grid mean (days) & $36.7(2012)$ & $43.1(2006)$ & 39.3 & 1.9 & $4.8 \%$ \\
\hline
\end{tabular}

by $13.72 \mathrm{~km}^{2}$, the area of the coarser grid cell, to determine the flash density. The overall pattern in Fig. 7 shows maxima over Florida and the Gulf Coast, and mirrors that shown in Holle et al. (2016) for 2005-14. Several locations in California, mainly in Monterey County, had no lightning flashes during the 26-yr period. The maximum value of 16.03 flashes $\mathrm{km}^{-2}$ occurred near Tampa, Florida, in Hillsborough County.

\section{TD results}

\section{a. Geographic distributions of annual TD activity}

Annual mean TD maps for the 26-yr period are presented in Fig. 8 for the four combinations of two audibility ranges ( 5 and $10 \mathrm{n} \mathrm{mi}$ ) and two flash requirement minima (one flash and two flashes). In all four maps, the maximum values occur over southern Florida near Naples, in Collier County. The Gulf Coast region from northern Florida westward through southeastern Texas also exhibits frequent TDs. Several local maxima are found over the Ouachita Mountains in southeastern Oklahoma and west-central Arkansas, as well as the southern Rocky Mountains, reflecting the role that higher topography plays in thunderstorm initiation (Banta 1990). TD values tend to decrease

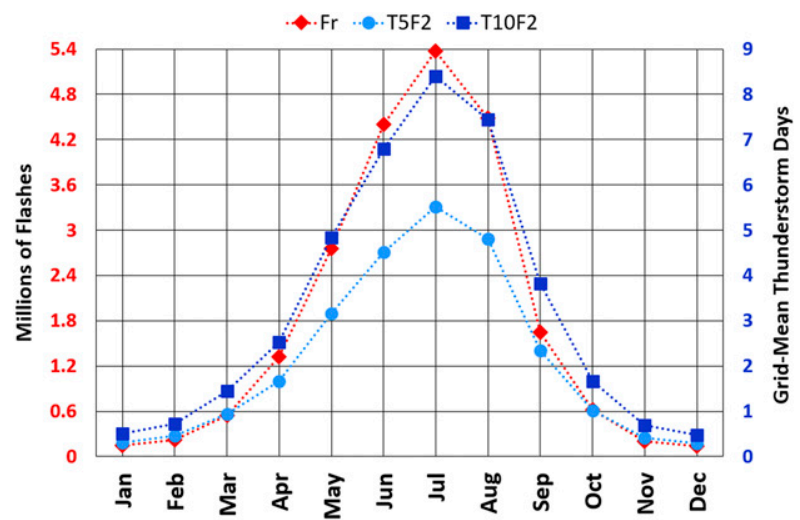

FIG. 5. Monthly mean number of lightning flashes in the CONUS in millions of flashes (red, left vertical axis), and grid-mean number of T5F2 (light blue) and T10F2 TDs (dark blue, right vertical axis) for the period 1993-2018. northward and westward from the Gulf Coast (with the exception of mountain regions), with values generally less than 9 days found mostly in the Pacific coast states.

The minimum, maximum, and grid-mean values for each of the maps are provided in Table 2. The TD grid means increase by about 14 days when increasing the audibility range from 5 to $10 \mathrm{n} \mathrm{mi}$, and decrease by about 6 TDs when a TD is defined by a minimum of two flashes instead of one flash. Changes in the maximum values which occurred in southern Florida are larger than those for the grid means. The increases in maximum TDs due to increasing the audibility range from 5 to $10 \mathrm{n}$ mi were 29.6 days (93.1 days for T5F1 to 122.7 days for T10F1) for the one-flash minimum definition, and 31.7 days (81.5 days for T5F2 to 113.2 days for T10F2) for the twoflash minimum definition. The decreases in maximum TDs due to increasing the minimum number of required flashes from one to two were 11.6 days (93.1 days for T5F1 to 81.5 days for T5F2) for the $5 \mathrm{n} \mathrm{mi}$ audibility range, and 9.5 days ( 122.7 days for $\mathrm{T} 10 \mathrm{~F} 1$ to 113.2 days for T10F2) for the $10 \mathrm{n} \mathrm{mi}$ audibility range.

Many of the subsequent sections more closely examine the NLDN-based TD distributions, using only one of the four combinations illustrated in Fig. 8. A cursory comparison of the surface-based TD distribution in Fig. 1 to those in Fig. 8 shows reasonable similarities to the intermediate NLDN-based distributions, T5F1 in Fig. 8a and T10F2 in Fig. 8d. Previous studies (Reap and Orville 1990, and Corbosiero and Lazear 2013) suggest that analyses based on the surface observations (Fig. 1)

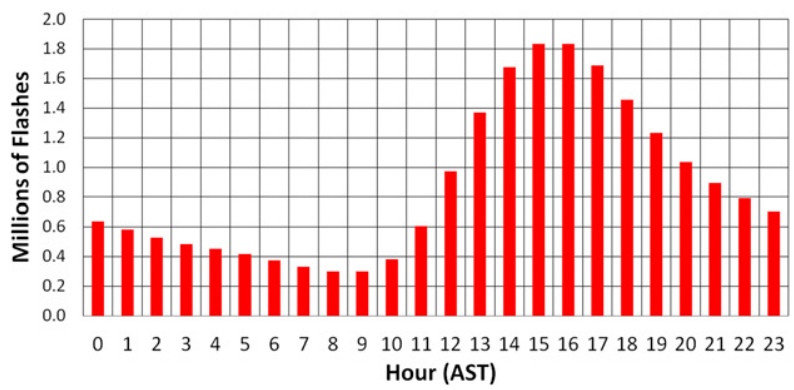

FIG. 6. Hourly mean total number of lightning flashes over the CONUS in millions of flashes. 


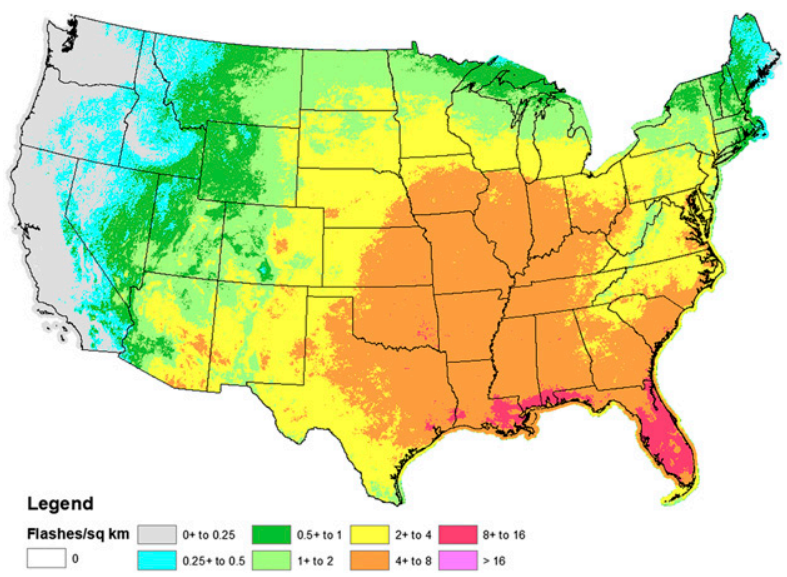

FIG. 7. Annual mean CG flash density map from 26 years of NLDN observations. Note the nonlinear scale.

underestimate thunderstorm activity compared to those based on NLDN observations. Also, requiring a minimum of two flashes in the TD determination to remove outliers as done in the ASOS algorithm is reasonable. These two factors aided in the decision to focus on the
$\mathrm{T} 10 \mathrm{~F} 2$ distributions with greater TD values than $\mathrm{T} 5 \mathrm{~F} 1$ in many of the remaining sections.

\section{b. Differences in results between one-flash and two-flash minimum thresholds}

As mentioned in section 2a, previous studies required a minimum of either one or two flashes during a specified time interval to occur within the audibility range of a grid cell in order to designate the cell as having experienced thunder. TDs in this paper were derived for both thresholds, as seen in Fig. 8. The spatial distribution of the impact of increasing the minimum decision threshold from one to two flashes for the $10 \mathrm{n} \mathrm{mi}$ audibility range is examined in Fig. 9. As indicated in the previous section, increasing the threshold from a minimum of one flash to a minimum of two flashes decreases the resulting number of TDs. The geographic distribution of these reductions is illustrated in Fig. 9a. The grid-mean reduction is the six TDs mentioned in section $4 \mathrm{a}$. Reductions of greater than eight TDs are found in the Southeast, and over mountain/valley regions in Colorado and New Mexico. Reductions of greater than

\section{Annual Mean Thunderstorm Days (1993-2018)}
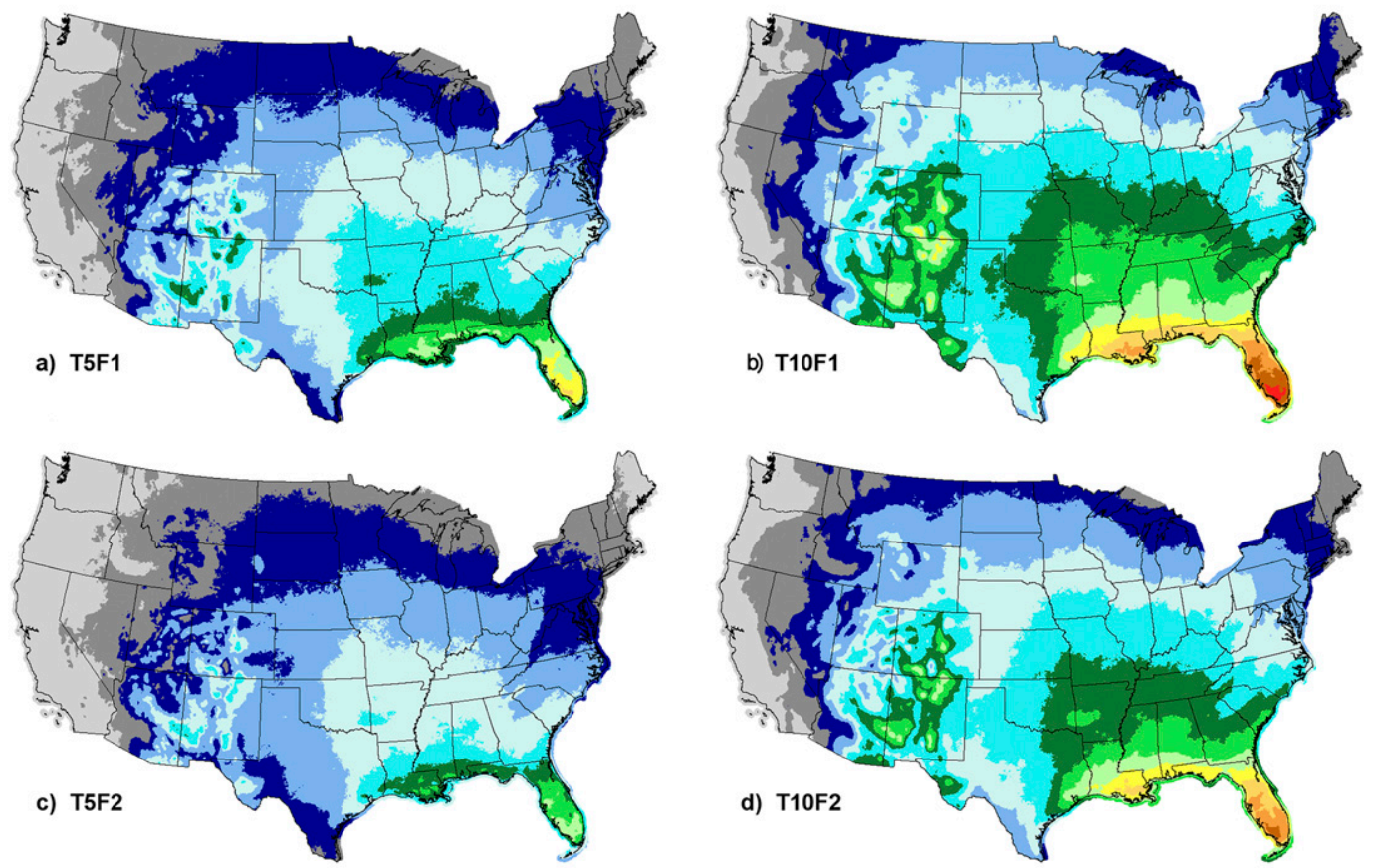

Legend

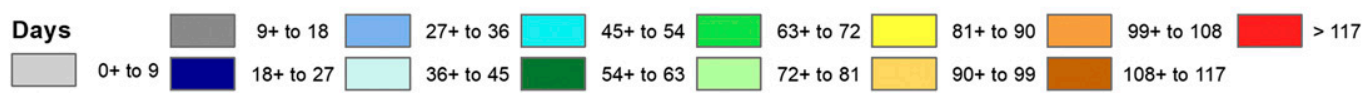

FIG. 8. Mean annual TD maps from a (left) $5 \mathrm{n}$ mi audibility range of thunder and a (right) $10 \mathrm{n}$ mi audibility range of thunder. (a),(b) One or more flashes within the audibility range were required to define a TD. (c),(d) Two or more flashes were required. 
TABLE 2. Map statistics for the four annual mean TD analyses (Fig. 8).

\begin{tabular}{lcrc}
\hline \hline Analysis & Minimum & Maximum & Grid mean \\
\hline T5F1 & 0.4 & 93.1 & 31.3 \\
T10F1 & 1.2 & 122.7 & 45.3 \\
T5F2 & 0.1 & 81.5 & 25.4 \\
T10F2 & 0.7 & 113.2 & 39.3 \\
\hline
\end{tabular}

12 TDs are confined to southern Florida, along the Gulf Coast, and near the San Luis Valley in southern Colorado and northern New Mexico. The maximum reduction of 16.4 TDs is found near the Florida Keys. Reductions of fewer than two TDs are located along the West Coast, with a minimum reduction of 0.2 days.

Consider a scenario in which two locations, $\mathrm{A}$ and $\mathrm{B}$, had the same number of one-flash minimum TDs during the 26-yr period, but A had fewer two-flash minimum TDs than B. Location A would then have had more occurrences of TDs determined from only one flash (possible outliers) than B. Based on this example, the regions with larger reductions from requiring a two-flash minimum instead of a one-flash minimum noted in the previous paragraph had more instances of TDs determined from what might be considered outliers. Smaller reductions in regions with fewer TDs and larger reductions in regions with more TDs in the one-flash minimum analysis would also be expected.

Figure $9 \mathrm{~b}$ examines the percent reduction in the annual mean TD values when the decision threshold is changed from a minimum of one to two flashes. The region with reductions of less than $16 \%$ (different shades of blue) covers $72.8 \%$ of the analysis domain.
Regions with greater than $16 \%$ reductions are primarily in California, Nevada, the Northwest, the upper Great Lakes, and the Northeast. The grid-mean percent reduction was $15.2 \%$, with values less than $8 \%$ on the western side of the Florida Peninsula, southwestern New Mexico and southeastern Arizona. Percent reduction values were greater than $48 \%$ at several locations along the Pacific coast, in areas with few TDs. The large reductions along the West Coast are not surprising given the infrequency of thunderstorms in the area where removing just a few TDs over the period by not meeting the two-flash minimum yields significant percent reductions.

\section{c. Year-to-year variation in annual TD grid-mean values}

The grid-mean values of the annual TD map results (not shown) provide a relatively straightforward way to compare the overall yearly and monthly variability of TDs. Figure $4 \mathrm{~b}$ shows the yearly variation in grid-mean TDs for all four combinations in each of the 26 years of the dataset. $\mathrm{T} 10 \mathrm{~F} 1$ values being greater than the $\mathrm{T} 5 \mathrm{~F} 1$ values and $\mathrm{T} 10 \mathrm{~F} 2$ values being greater than the $\mathrm{T} 5 \mathrm{~F} 2$ values are not surprising given that thunder is assumed to be heard over a larger area for a 10-nmi audibility range compared to a $5 \mathrm{n}$ mi audibility range. Statistics for the yearly T5F1, T10F1, T5F2, and T10F2 annual values are also given in rows $2-5$ of Table 1 . The difference between mean annual T10F1 and T5F1 values is 14.0 TDs, and the difference between $\mathrm{T} 10 \mathrm{~F} 2$ and T5F2 values is 13.9 TDs.

Figure 4a illustrates different patterns of increases and decreases between the yearly flash frequencies (Fr) and TDs (T10F2). As mentioned in section 3, 2003-06 were
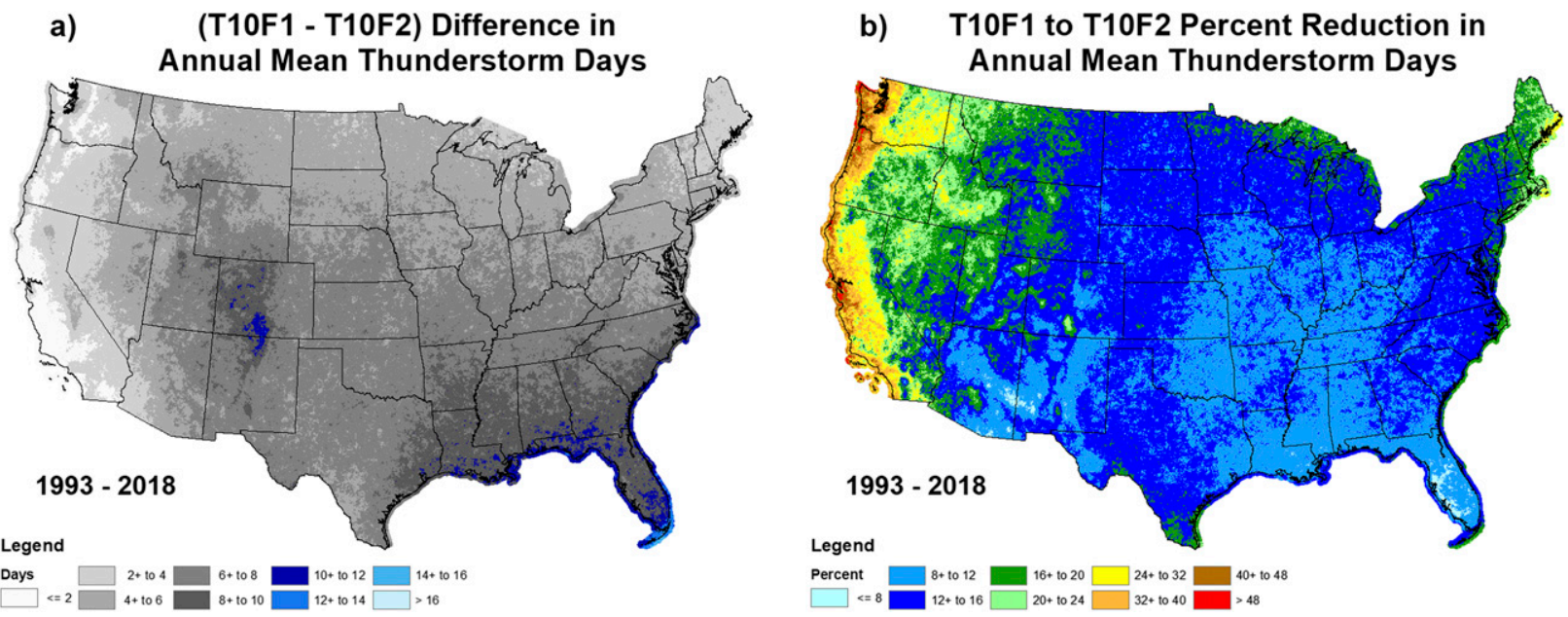

FIG. 9. (a) Differences between the one-flash minimum and the two-flash minimum TD grid cell values for the $10 \mathrm{n}$ mi audibility range, and (b) the percent reduction in the TD grid cells values due to increasing the minimum number of flashes required to define a TD from one to two, also for the $10 \mathrm{n}$ mi audibility range. 
the four years with the greatest number of lightning flashes, all greater than 25 million. These years were also four of the nine years with greater than 40 gridmean T10F2 TDs. In contrast, the nine years prior to the 2002-03 NLDN upgrade all had flash totals below the 26-yr mean of 22 million flashes, while three of the years $(1994,1996$, and 1998) had T10F2 grid-mean TDs greater than the 26-yr mean of 39.3 TDs. In fact, 1994 was ranked third in $\mathrm{T} 10 \mathrm{~F} 2$ grid-mean TDs, behind only 2006 and 2004. The lightning flash totals decreased dramatically from 24.5 million flashes in 2011 to 18.9 million flashes in 2012, a $22.9 \%$ decrease. The corresponding drop in T10F2 grid-mean TDs was only 0.5 days (from 37.2 to 36.7 days), a 1.3\% decrease. From 2013 to 2014, the annual flash totals rebounded from 19.2 to 23.6 million (22.9\%), with a corresponding increase in T10F2 grid-mean TDs from 37.8 to $38.1(0.8 \%)$. The last two examples were after the 2002-03 NLDN upgrade. The greater variation in Fr results compared to the variation in $\mathrm{T} 10 \mathrm{~F} 2$ results evident in Fig. 4a is confirmed by the greater coefficient of variation for flash frequencies of $13.3 \%$ compared to $4.8 \%$ for the T10F2 grid-mean TDs (Table 1).

The network upgrades noted in section $2 \mathrm{~b}$, particularly those in the first ten years of the 26-yr period, markedly improved the CG flash DE. As the NLDN DE increased, newly detectable flashes often occurred near prior-detectable flashes, increasing the flash frequencies, but not proportionately changing the TD totals. This finding agrees with results from Bourscheidt et al. (2012) who demonstrated that thunderstorm hours or days provide a more stable long-term measure of thunderstorm activity than lightning frequency, especially during periods of frequent LLS improvements. Flash frequencies can also exhibit greater year-to-year variability than that from TDs due to natural shifts in the duration and areal extent of convective activity and the efficiency of the type of convection experienced to produce CG flashes.

\section{d. Differences in results between 5 and $10 \mathrm{n} \mathrm{mi}$ audibility ranges}

As noted in section $4 \mathrm{a}$, the TD grid means increase by about 14 days when increasing the audibility range from 5 to $10 \mathrm{n} \mathrm{mi}$. Reasons for these increases will now be examined using the two-flash minimum results. The analysis domain for all of the maps is composed of 9076521 cells. A cell is assigned a value of 1 (a TD, as shown in Fig. 3c) if at least two CG lightning flashes occur within $5 \mathrm{n}$ mi of the center of the cell for T5F2 and within $10 \mathrm{n} \mathrm{mi}$ for T10F2 on the day being analyzed. For a given day, multiple lightning flashes had to fall within the $5 \mathrm{n}$ mi audibility range for a T5F2 grid cell to be assigned a value of 1 indicating a TD. Since the area covered by the $5 \mathrm{n} \mathrm{mi}$ audibility range is a subset of the
$10 \mathrm{n}$ mi audibility range, all cells with T5F2 $=1$ would also have $\mathrm{T} 10 \mathrm{~F} 2=1$. A value of $\mathrm{T} 10 \mathrm{~F} 2=1$ could also be triggered by two or more flashes at distances between the two audibility ranges, or with at least one flash in the $5 \mathrm{n}$ mi audibility range and at least one flash between the two ranges. If the $\mathrm{T} 5 \mathrm{~F} 2$ grid cell values are subtracted from the T10F2 grid values (T10F2-T5F2) on that day, the resulting grid cells with values of 1 identify locations where the TD was identified with at least one flash located from 5 to $10 \mathrm{n} \mathrm{mi}$ of a given grid cell. In most circumstances, thunder is audible when $\mathrm{T} 5 \mathrm{~F} 2=1$, but thunder might not be heard when at least one of the required flashes is between 5 and $10 \mathrm{n} \mathrm{mi}$ from the location $(\mathrm{T} 10 \mathrm{~F} 2=1)$, especially if all required flashes are at distances greater than $5 \mathrm{n} \mathrm{mi}$. For this reason the $\mathrm{T} 10 \mathrm{~F} 2$ values may overestimate the number of events in which thunder would be audible.

Figure 10a shows the mean annual difference map (T10F2 minus T5F2) for the 1993-2018 period. Regions with greater differences indicate areas where T10F2 values are more likely to overestimate the number of days when thunder is heard. Greater differences are generally found along the Gulf Coast and mountain regions in Colorado and New Mexico where greater values of T5F2 and T10F2 are shown in Figs. 8c and 8d. The maximum difference of 41.6 TDs is found in Martin County, FL where the T10F2 value was 101.0 TDs and the $\mathrm{T} 5 \mathrm{~F} 2$ value was $59.4 \mathrm{TDs}$. The ratio of T10F2 values to T5F2 values is depicted in Fig. 10b. The ratio for the Martin County, FL example above is 1.70 , indicating that the number of T10F2 TDs generated by at least one flash from 5 to $10 \mathrm{n} \mathrm{mi}$ of the grid cell is $70 \%$ of those produced by at least two flashes within $5 \mathrm{n} \mathrm{mi}$, implying that 1 out of every 2.4 TDs identified had at least one flash beyond $5 n$ mi from the grid cell. Much of the central United States falls within the light blue color indicating a ratio less than 1.6. A few grid cells along the West Coast had T10F2 value to $\mathrm{T} 5 \mathrm{~F} 2$ value ratios greater than 4.4.

\section{e. TD-topography relationships}

Figure 11 relates the T10F2 TD results to topography in the western United States. Maxima of more than 72 TDs per year are found over several mountain features in Colorado and New Mexico, including Pikes Peak and the Rampart Range in central Colorado, the San Juan Mountains in southwest Colorado, the Sangre de Cristo Mountains in south-central Colorado and northeast New Mexico, the Sacramento Mountains in southcentral New Mexico, and the Mogollon Mountains of southwest New Mexico. An axis of greater TD values extends from this last maximum northwestward into central Arizona along the Mogollon Rim. A local minimum in the $27+$ to 36 TD category is found over the San 
a) (T10F2 - T5F2) Difference between Annual Mean Thunderstorm Days

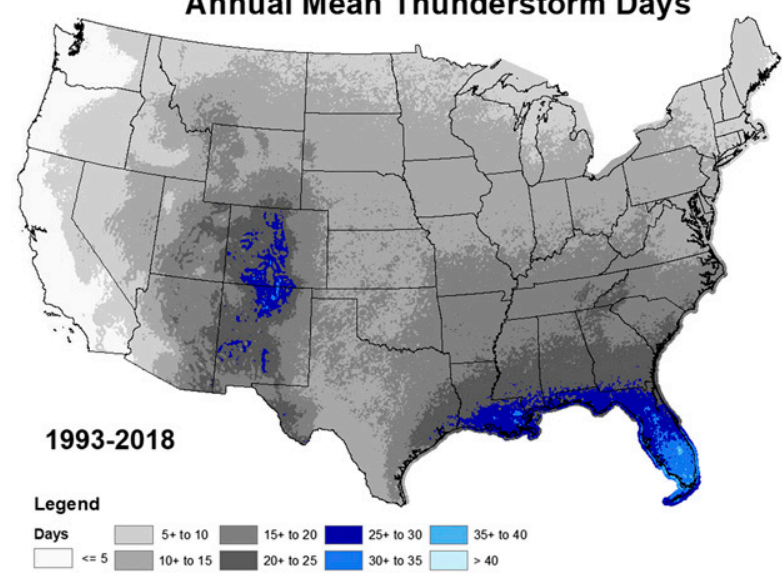

b) T10F2 to T5F2 Ratio of Annual Mean Thunderstorm Days

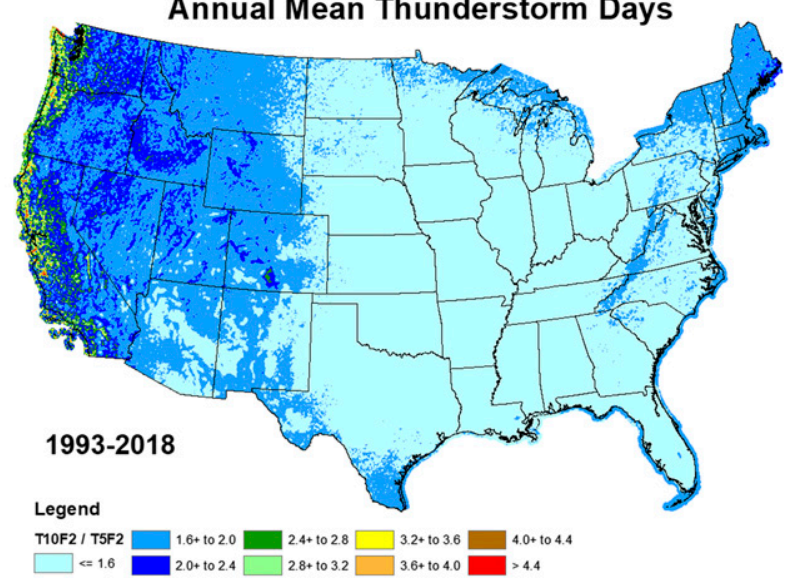

FIG. 10. (a) Differences between the T10F2 and T5F2 grid cell values, and (b) ratio of the T10F2 and T5F2 grid cells values.

Luis Valley in south-central Colorado, a region with T10F2/T5F2 ratios in the $2.4+$ to 2.8 category (Fig. 10b). The greatest ratio within the valley was 2.78 , at a location with $\mathrm{T} 10 \mathrm{~F} 2=37.5 \mathrm{TDs}$ and $\mathrm{T} 5 \mathrm{~F} 2=13.5$ TDs indicating that more than half of the T10F2 thunderstorms at this location were identified with at least one flash beyond $5 \mathrm{n} \mathrm{mi}$. Another discernable TD maximum is seen in Fig. 8d over the Ouachita Mountains in west-central Arkansas and southeast Oklahoma. The correspondence of the TD distribution to mountain features is reassuring given the influence of elevated topography on thunderstorm initiation. Previous surface observation-based TD climatologies were unable to fully illustrate the TD maxima over mountains observed in this study due to the relative sparseness of observers at higher elevations in the mountains compared to valley locations.

\section{f. Monthly variation in TDs}

The monthly grid-mean TDs for the T5F2 and T10F2 cases are presented in Fig. 5, in addition to the lightning flash frequency graph. As with the monthly flash distributions the lowest TD values are in December and the greatest in July. The monthly mean graphs for TDs and flash frequency, while similar in shape, exhibit some a) Annual Mean Thunderstorm Days (1993-2018)

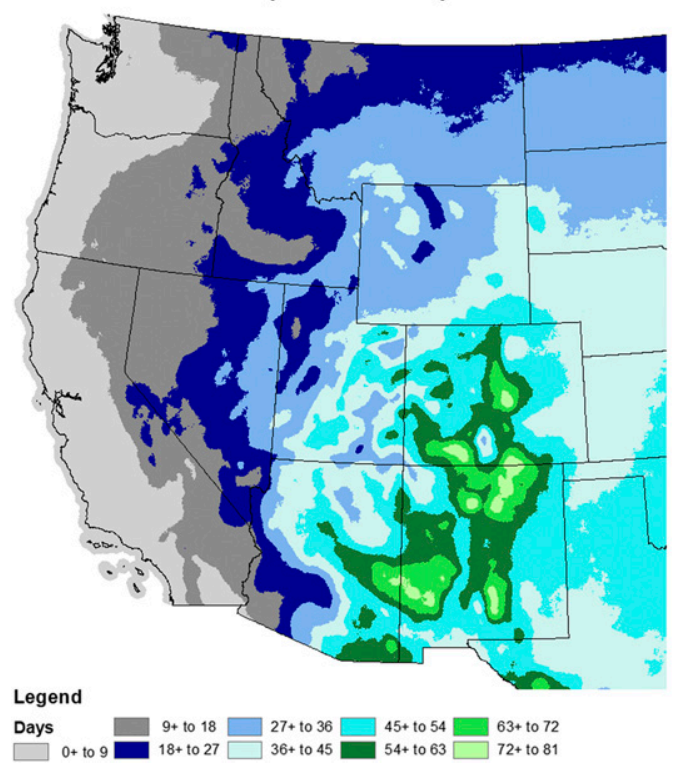

b) Topographical Map of the Western United States

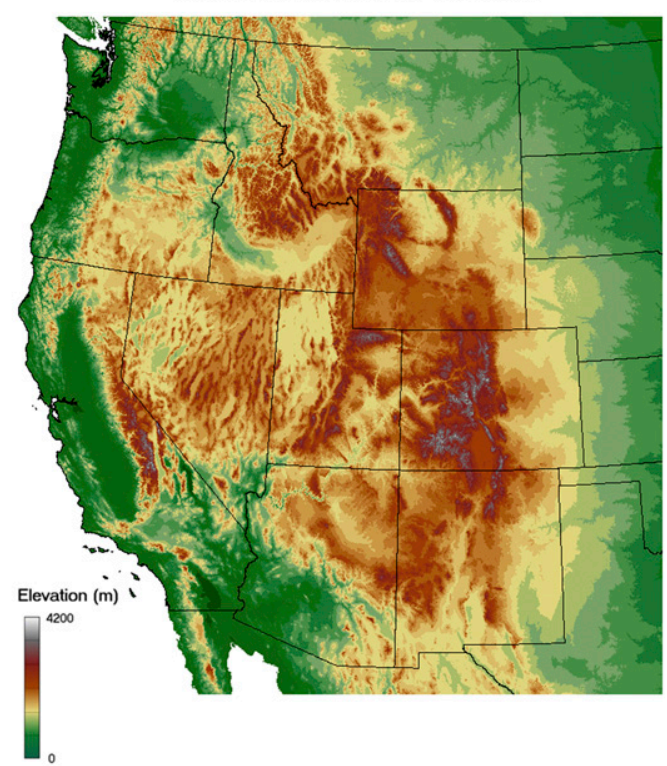

FIG. 11. (a) A portion of the T10F2 TD map from Fig. 8d and (b) a topographical map of the western United States. 


\section{Monthly Mean Thunderstorm Days (1993-2018)}
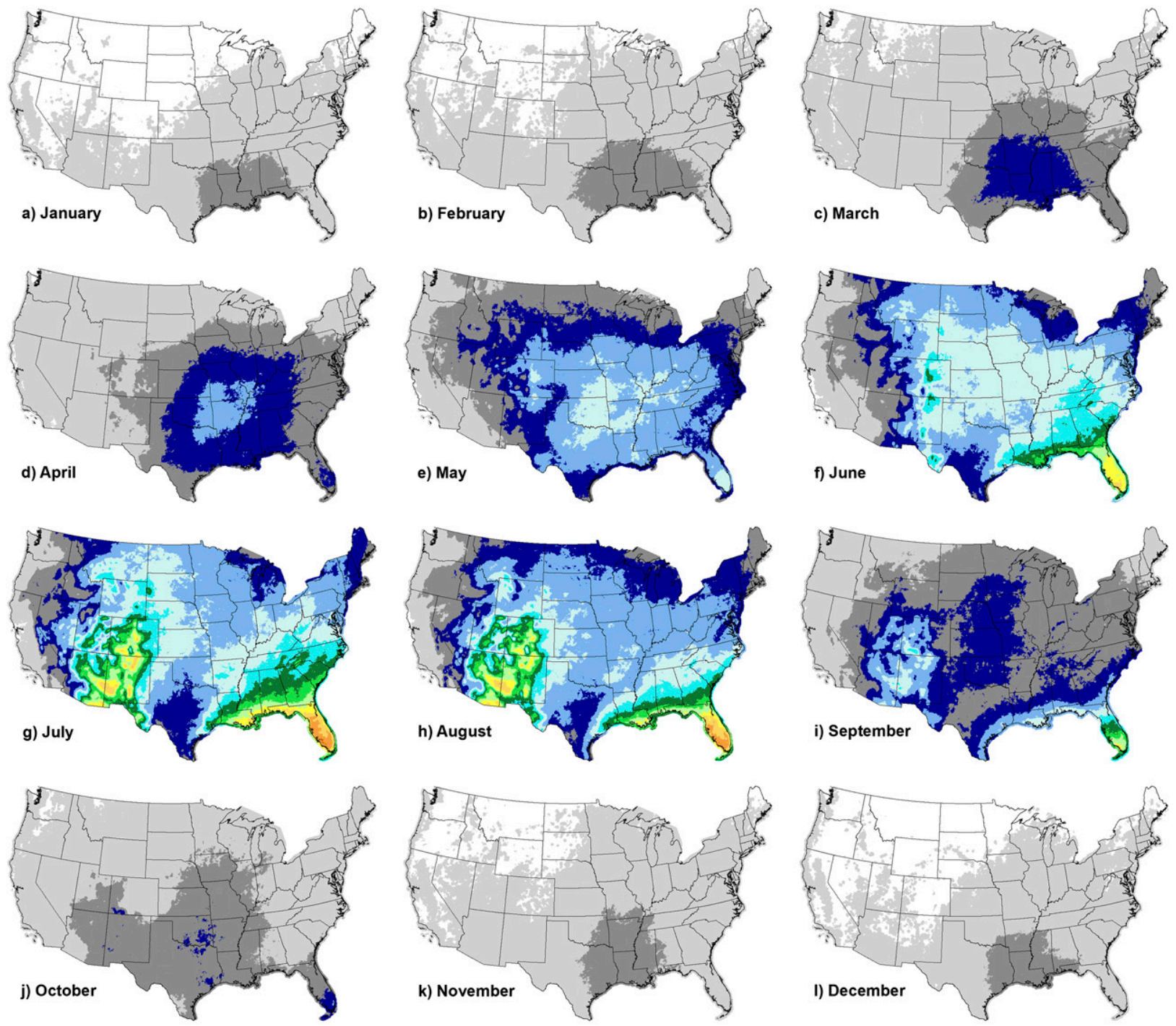

Legend

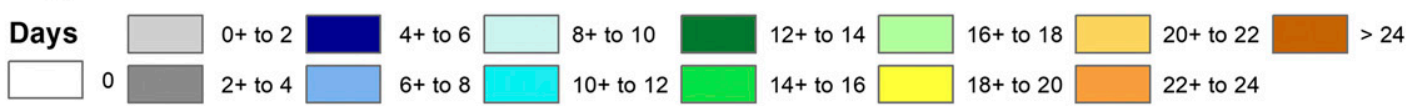

FIG. 12. Monthly mean TD maps for $10 \mathrm{n}$ mi audibility (T10F2) for the years 1993-2018. Regions with zero values were without TDs for that month for the entire 26 years.

differences. For example, the number of flashes in June and August are about the same, but August has about 7.4 T10F2 grid-mean TDs compared to 6.8 grid-mean TDs in June. The summer months (June, July, and August) contribute about $56.5 \%$ of the annual T10F2 TDs while $65.2 \%$ of annual CG flashes occur during the summer.

\section{g. The geographic distribution of monthly TDs}

Figure 12 shows the twelve monthly-mean T10F2 TD maps. From November through February, mean
TD maxima are fewer than 4 TDs per month and appear mostly in the south-central U.S. states of Louisiana, Texas, Arkansas, and Mississippi. The maxima increase to more than 5.4 TDs during March in southwestern Arkansas, and more than 7.1 TDs during April in eastern Oklahoma. By May, a maximum of more than 10 TDs is found near Pikes Peak in Colorado. Other regions with more than 8 TDs are found in the Front Range of the Rocky Mountains, from northern Texas into Oklahoma, eastern Kansas and western Missouri, and over the southern part of the 


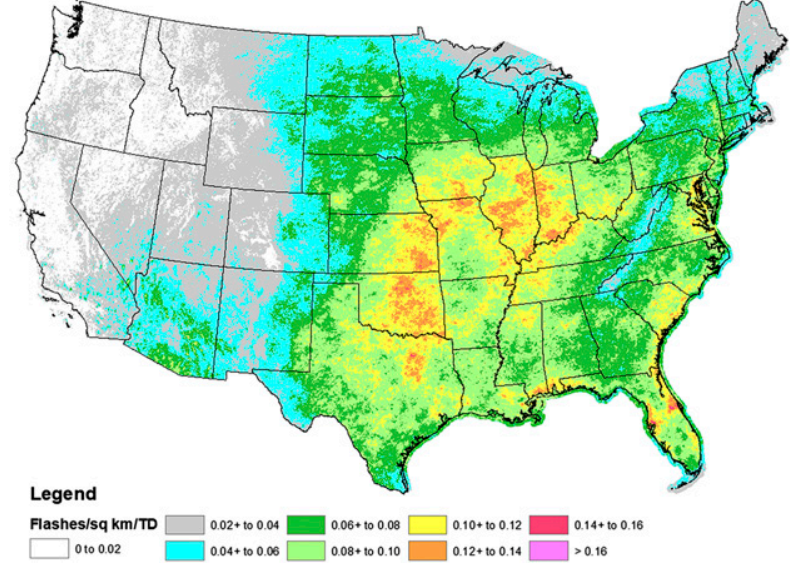

FIG. 13. Annual mean flash density per TD map for the period 1993-2018. Each grid cell has dimensions of $3704 \mathrm{~m} \times 3704 \mathrm{~m}(2 \mathrm{n}$ $\mathrm{mi} \times 2 \mathrm{n} \mathrm{mi}$ ), an area of $13.72 \mathrm{~km}^{2}$.

Florida Peninsula. The June maximum of greater than 20 days is found in Florida. Maxima exceeding 22 TDs remain in Florida during July and August, with values greater than 20 TDs in parts of the southern Rockies. Values greater than 18 TDs also extend along the Gulf Coast from Florida through Louisiana during those months. TDs decrease rapidly in September except in southern Florida, and continue to decrease during October.

\section{Annual mean flash density per TD (flash rate) results}

Three of the studies cited in sections 1 and 2a, Huffines and Orville (1999), Mäkelä et al. (2011), and Mäkelä et al. (2014), took analyses of CG lightning flashes one step further by dividing the flash densities by either TDs or thunderstorm hours, to obtain a mean daily or hourly flash rate. Equivalent values were determined for this study. Since the flash densities shown in Fig. 7 were combined into $3704 \mathrm{~m} \times 3704 \mathrm{~m}$ grid cells, $4 \times 4$ subsets of the $926 \mathrm{~m} \times 926 \mathrm{~m} \mathrm{T10F} 2$ grid were averaged to determine TD values on the $3704 \mathrm{~m} \times 3704 \mathrm{~m}$ grid. The flash density values were then divided by the averaged T10F2 TD values to yield the mean daily rates (flash density per TD) shown in Fig. 13. The maximum annual flash rate of 0.163 flashes $\mathrm{km}^{-2}$ per TD is found just east of Orlando, in Orange County, FL. Other maxima exceeding 0.12 units are found near Tampa, FL, Biloxi, MS, and in an arc from northeastern Texas northward through Oklahoma, eastern Kansas, northern Missouri, then southeastward over Illinois and Indiana. The higher flash rate values can be due to thunderstorms with intense lightning activity, from long-lived convective systems with long durations, or multiple thunderstorms occurring within a TD.

The double counting of TDs during thunderstorm events that span midnight AST was mentioned in section 2a. As noted in Wallace (1975), nocturnal thunderstorms are frequent in regions of the Great Plains from central Oklahoma through Kansas and the Dakotas, and through the northern Mississippi Valley. The annual TDs in these regions can be overestimated due to double counting on those days when a thunder event spanned midnight from one day to the next, but no other thunderstorms occurred on either day. While such occurrences might be infrequent, the actual annual mean TDs would be less if the events were only counted once. In that case, the flash density per TD maxima apparent in Fig. 13 from northern Texas through Oklahoma, Kansas, northern Missouri, southern Iowa, and northern Illinois would be underestimated.

\section{Variability of TD patterns within the period studied}

The 26 annual, grid-mean T10F2 TD values are shown in Fig. 14, with the first 25 years in the study subdivided into five, 5-yr groups labeled I through V. Mean annual T10F2 maps for each 5-yr period are shown in Figs. 15a-e. Note in Fig. 15a how the mean number of TDs during the

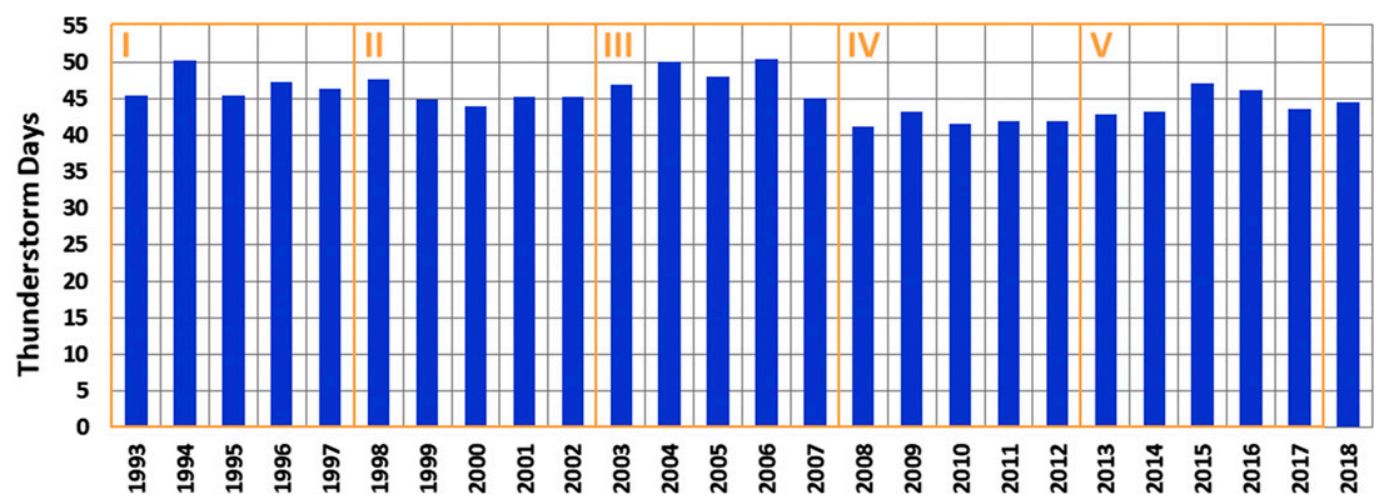

FIG. 14. Annual grid-mean TDs (T10F2) for the analysis domain based on results from Fig. 4. The orange boxes outline the 5-yr groups evaluated in this paper. 


\section{Annual Mean Thunderstorm Days}
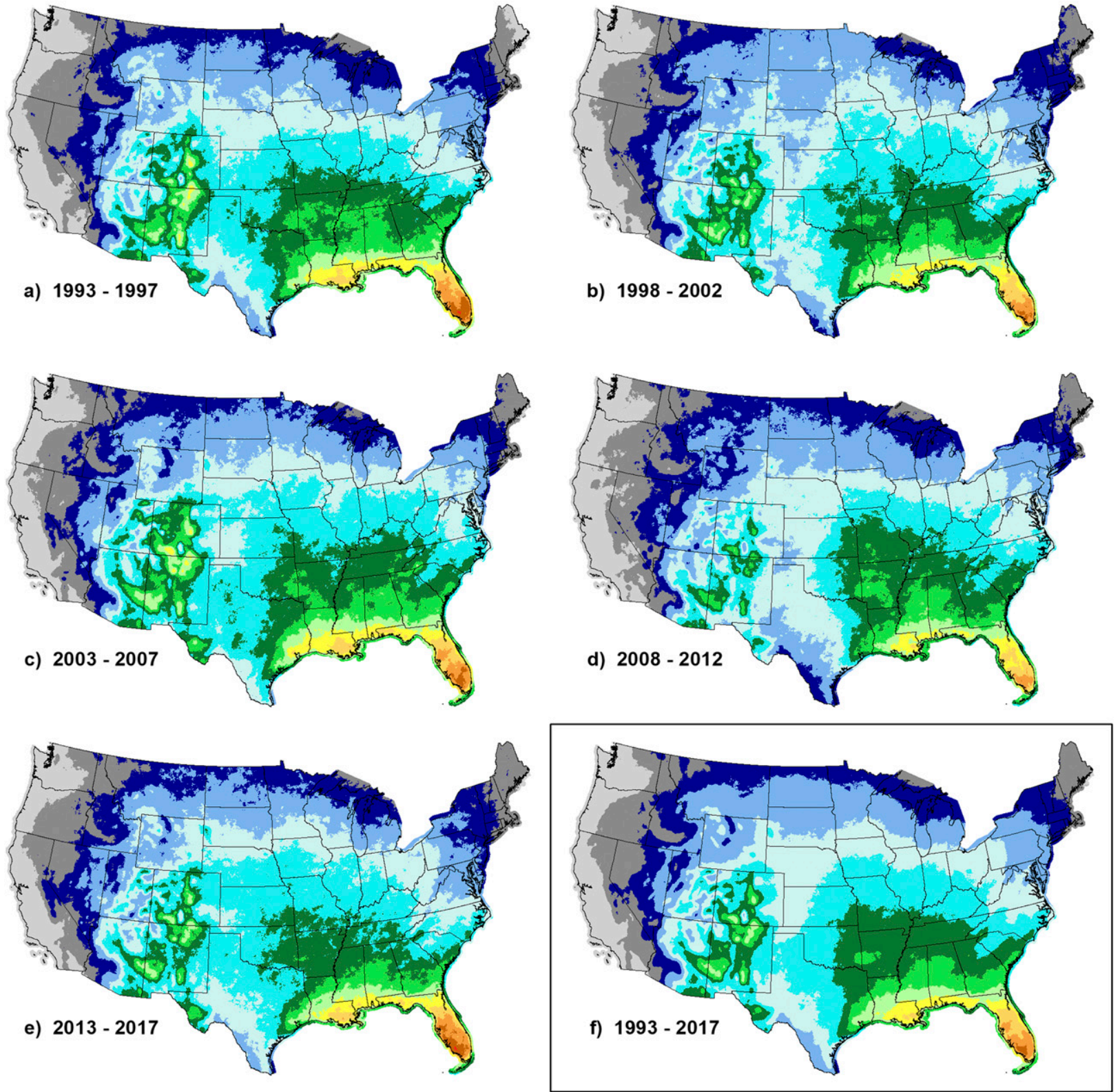

\section{Legend}

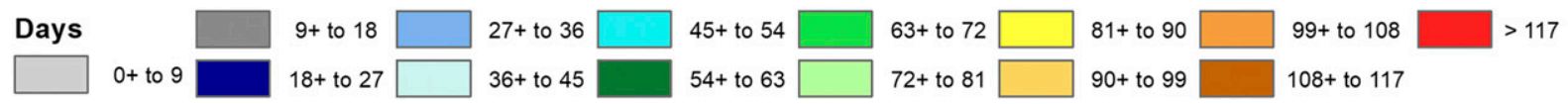

FIG. 15. Mean annual T10F2 TD distributions for each of the 5-yr periods, (a) I, (b) II, (c) III, (d) IV, and (e) V, and (f) for the entire 25-yr period, 1993-2017.

1993-97 period is greater over the southern Rockies and southern Florida than the 25-yr mean (Fig. 15f). In contrast, the number of TDs during the 2008-12 period (Fig. 15d) is less in these two regions. Deviations of the 5 -yr means from the 25-yr means (5-yr minus 25-yr) are shown in Fig. 16. The most striking variability is over Texas where large positive deviations of greater than 12 TDs occurred during 2003-07, while equally large negative deviations occurred during the subsequent period, 200812. Three of the five 5-yr maps (Figs. 16a,c,d) show similar 


\section{Annual Mean Thunderstorm Days Deviations from 25-year Mean}
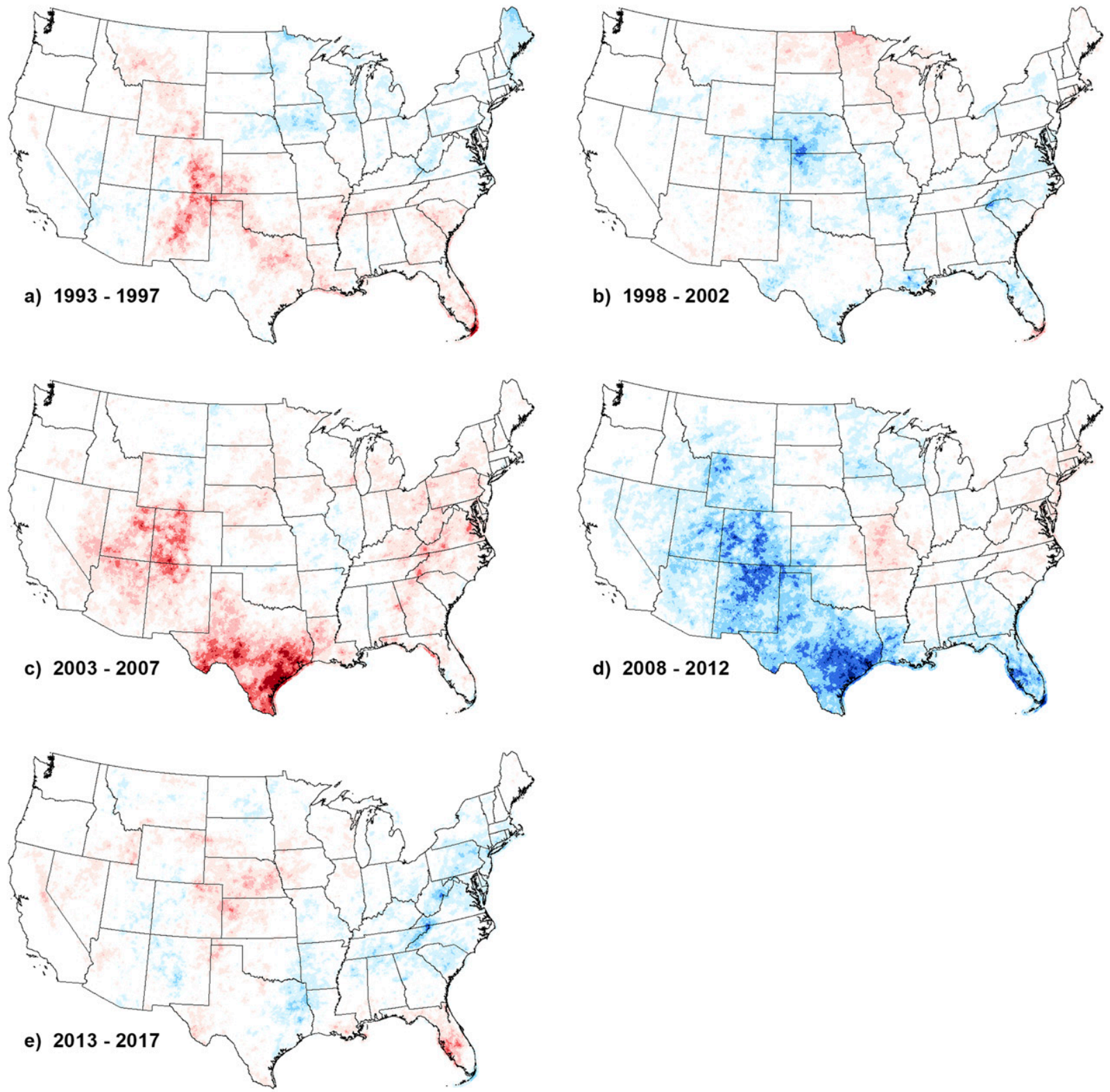

\section{Legend}

Days $<-12$ -12 to -9 -9 to -6 -6 to -3 -3 to 3 3 to 6 6 to $9 \square 9$ to 12 $>12$

FIG. 16. Distributions of the mean annual TD deviations of the 5-yr period T10F2 values from their 25-yr mean values for periods (a) I, (b) II, (c) III, (d) IV, and (e) V.

spatial patterns with large deviations over Colorado and New Mexico extending southeastward into Texas.

Several different indices related to interannual climate variability were examined as possible contributors to the variability in TDs seen in Figs. 14-16. Among those examined were the Pacific decadal oscillation (PDO) index, the Southern Oscillation index (SOI), the Atlantic multidecadal oscillation (AMO) index, 
a) Annual Mean Pacific Decadal Oscillation Index (PDO)

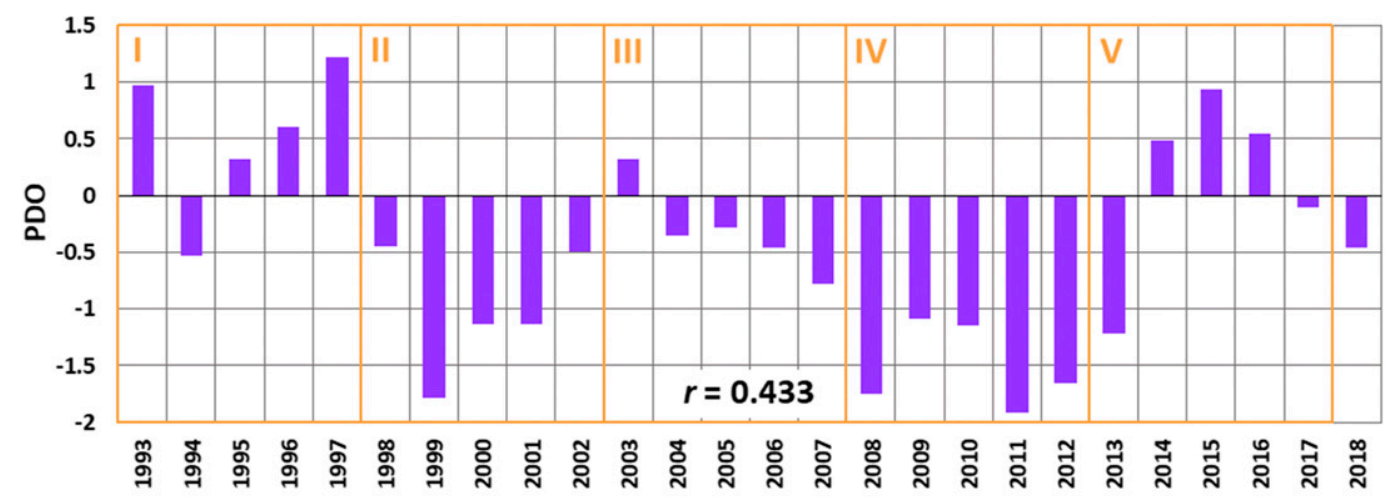

b) Annual Mean Southern Oscillation Index (SOI)

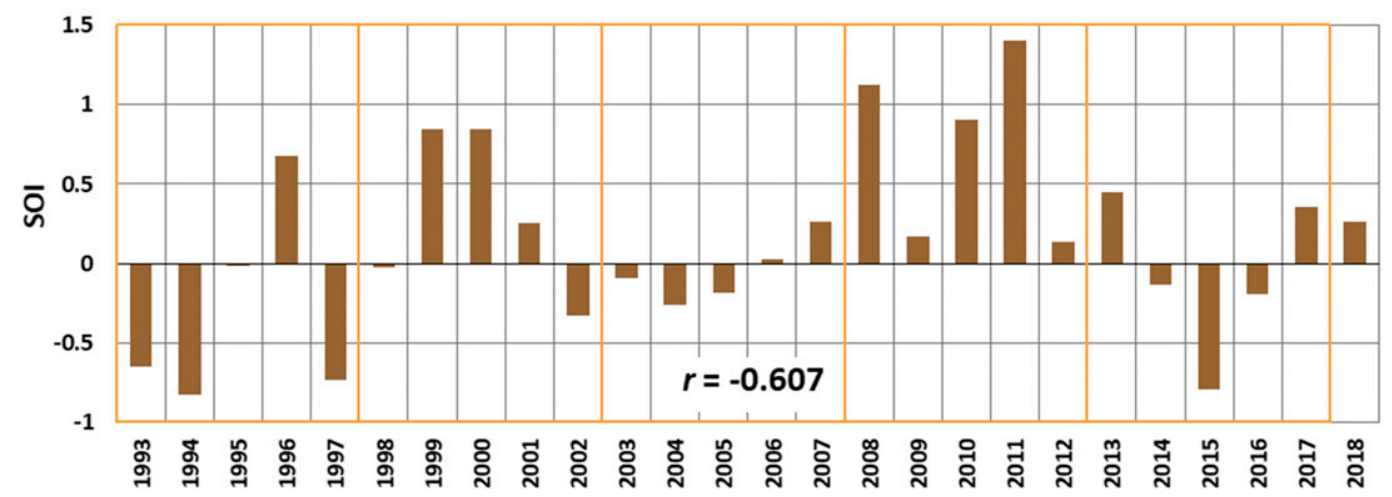

FIG. 17. Plots of the annual mean monthly values of (a) the PDO and (b) the SOI for the 26-yr period 1993-2018. The orange boxes delineate the 5-yr periods. PDO values tend to be positive (negative) when warmer (colder) waters reside along the Pacific coast of North America, and SOI values tend to be positive (negative) during La Niña (El Niño) events.

and the multivariate ENSO index version 2 (MEI.v2). Monthly values of these indices were downloaded, respectively, from NCDC (2019a), NCDC (2019b), ESRL (2019a), and ESRL (2019b), and averaged for each year from 1993 to 2018. The correlation coefficient $(r)$ between each index and the yearly grid-mean T10F2 TDs was then computed. Graphs for the PDO and SOI are presented in Fig. 17. The SOI versus TD correlation coefficient was -0.607 , the greatest in magnitude of any of the four $r$ values, including that for the other ENSO related index, MEI.v2 ( $r=0.539$, not shown). The $r$ value for PDO versus TD was next largest at 0.433 , while the $r$ value for AMO versus TD was only 0.027 (not shown).

The SOI is positive during the cold Eastern Pacific phase of ENSO (La Niña) and negative during the warm Eastern Pacific phase of ENSO (El Niño). The negative $r$ value for the SOI versus TD implies that a greater number of TDs over the CONUS would be expected in El Niño years than in La Niña years. Since most thunderstorms occur in the summer, and produce most of the summertime precipitation, surpluses of precipitation might be expected during El Niño periods in regions of positive TD deviations, and deficits of precipitation could be expected in regions of negative deviations during La Niña periods. The SOI index values for three out of the five years from 1993 to 1997 are negative, implying overall El Niño conditions for that 5-yr period. The pattern of positive deviations in the TDs apparent in Fig. 16a is consistent with Fig. 18a from Hu and Feng (2012) that shows an axis of positive summertime precipitation anomalies through Colorado and into eastern Texas and Louisiana during El Niño. All five years, 2008-12, have positive SOI values implying La Niña conditions. The pattern of negative deviations in TDs in Fig. 16d is also consistent with the axis of negative anomalies extending southeastward from Colorado into North Texas during La Niña (Fig. 18b). However, the strong positive TD deviation pattern for 2003-07 (Fig. 16c) has weak SOI values when small summertime precipitation anomalies might be expected. Atmosphericocean processes that influence the SOI values are only a subset of those influencing the development of 
(a)

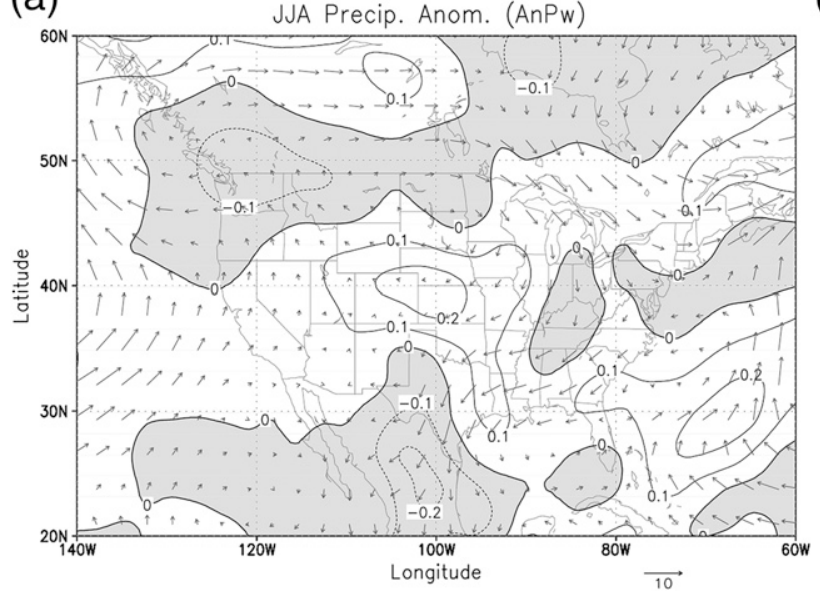

(b)

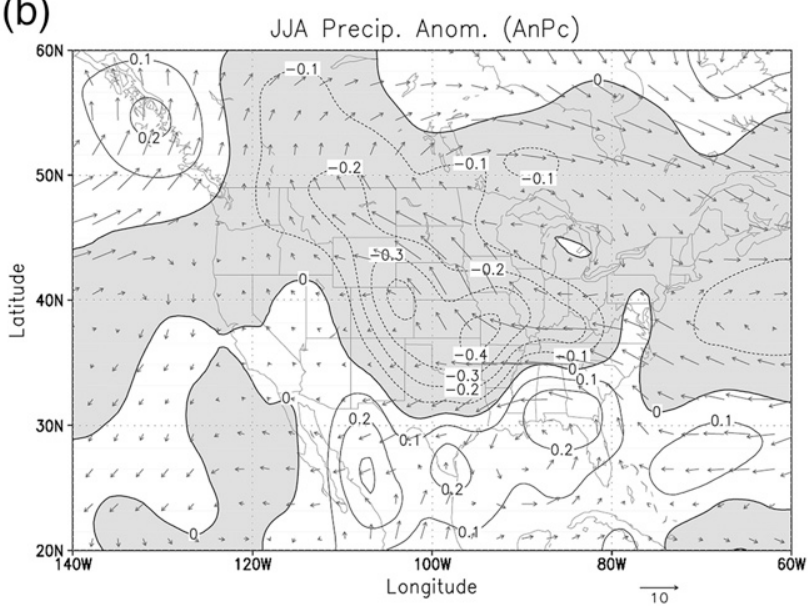

FIG. 18. (a),(b) From Figs. 8b and 8c in Hu and Feng (2012), respectively, illustrating simulated summertime precipitation rate anomalies $\left(\mathrm{mm} \mathrm{day}^{-1}\right)$ from ENSO neutral conditions during (a) El Niño and (b) La Niña events.

thunderstorms and the production of summertime precipitation over the CONUS.

\section{Conclusions}

CG lightning flash data from the NLDN for the 26 years, 1993-2018, can be used to construct a TD climatology that provides a more complete assessment of thunderstorm activity over the contiguous United States than that available from previous climatologies derived from the surface observing stations. This is especially true in remote and mountainous regions of the western United States. Flash density maps have all but superseded TD maps since the inception of the NLDN almost 30 years ago, and the mean annual flash density map here (Fig. 7) shows many similarities to those from previous studies. The annual flash counts exhibit considerably more variability than the annual grid-mean TD values (Fig. 4a and Table 1). This agrees with the conclusion by Bourscheidt et al. (2012) that TD estimates provide a more stable measure of thunderstorm activity than flash frequencies during periods with system upgrades, as experienced by the NLDN during the 26-yr period studied. TD activity peaks during June, July, and August with $56.5 \%$ of all gridmean TDs occurring during the summer, compared to $65.2 \%$ of the CG lightning flashes. Increasing the minimum number of required flashes used to define a TD from 1 to 2 leads to reductions from $5.5 \%$ to over $48 \%$ in the number of TDs identified for an audibility range of $10 \mathrm{n} \mathrm{mi.} \mathrm{Increasing} \mathrm{the} \mathrm{assumed} \mathrm{thunder} \mathrm{au-}$ dibility from 5 to $10 \mathrm{n} \mathrm{mi}$ when at least 2 flashes are required leads to increases in TD estimates from $19 \%$ to over $340 \%$, with the greatest increases along the
West Coast of the United States where thunderstorms are infrequent. Results using a $10 \mathrm{n} \mathrm{mi}(5 \mathrm{n} \mathrm{mi})$ audibility range probably overestimate (underestimate) the occurrence of audible thunder.

The interannual variability of TDs for the T10F2 audibility results are most highly correlated (in a negative sense) with the SOI index, an ENSO measure. The patterns of TD deviations computed for 5-yr subsets of a 25-yr period from the study are at times, but not always, consistent with the summertime precipitation anomalies over the CONUS expected from ENSO.

Acknowledgments. The lightning flash data used in this study were obtained from the NCEI. I thank Mr. Stuart Hinson for facilitating data access. I also thank Col. Jennifer Alexander and Lt. Col. Robert Wacker, faculty colleagues at the U.S. Air Force Academy, for their insightful comments about this research. I am also indebted to the anonymous reviewers of this and previous versions of this paper for their helpful recommendations.

\section{REFERENCES}

Aich, V., R. Holzworth, S. J. Goodman, Y. Kuleshov, C. Price, and E. Williams, 2018: Lightning: A new essential climate variable. Eos, Trans. Amer. Geophys. Union, 99, https://doi.org/10.1029/ 2018 EO104583.

Alexander, W. H., 1915: Distribution of thunderstorms in the United States. Mon. Wea. Rev., 43, 322-340, https://doi.org/ 10.1175/1520-0493(1915)43<322:DOTITU>2.0.CO;2.

Banta, R. M., 1990: The role of mountain flows in making clouds. Atmospheric Processes over Complex Terrain, Meteor. Monogr., No. 23. Amer. Meteor. Soc., 229-283.

Boccippio, D. J., K. L. Cummins, H. J. Christian, and S. J. Goodman, 2001: Combined satellite- and surface-based estimation of the 
intracloud-cloud-to-ground lightning ratio over the continental United States. Mon. Wea. Rev., 129, 108-122, https://doi.org/ 10.1175/1520-0493(2001)129<0108:CSASBE > 2.0.CO;2.

Bourscheidt, V., K. L. Cummins, O. Pinto Jr., and K. P. Naccarato, 2012: Methods to overcome lightning location system performance limitations on spatial and temporal analysis: Brazilian case. J. Atmos. Oceanic Technol., 29, 1304-1311, https://doi.org/10.1175/JTECH-D-11-00213.1.

Brown, C. E., Ed., 1998: Coefficient of variation. Applied Multivariate Statistics in Geohydrology and Related Sciences, Springer, 155-157.

Changery, M. S., 1981: National thunderstorm frequencies for the contiguous United States. U.S. Nuclear Regulatory Commission Rep. NUREG/CR-2252, 57 pp.

Changnon, S. A., 1988: Climatography of thunder events in the conterminous United States. Part I: Temporal aspects. J. Climate, 1, 389-198, https://doi.org/10.1175/1520-0442(1988) 001<0389:COTEIT>2.0.CO;2.

_ 2001a: Thunderstorm rainfall in the conterminous United States. Bull. Amer. Meteor. Soc., 82, 1925-1940, https://doi.org/ 10.1175/1520-0477(2001)082<1925:TRITCU > 2.3.CO;2.

_ 2001b: Assessment of the quality of thunderstorm data at firstorder stations. J. Appl. Meteor., 40, 783-794, https://doi.org/ 10.1175/1520-0450(2001)040<0783:AOTQOT $>2.0 . C O ; 2$.

__ 2003: Geographical and temporal variations in thunderstorms in the contiguous United States during the 20th Century. Phys. Geogr., 24, 138-152, https://doi.org/10.2747/ 0272-3646.24.2.138.

Clodman, S., and W. Chisholm, 1996: Lightning flash climatology in the southern Great Lakes region. Atmos.-Ocean, 34, 345-377, https://doi.org/10.1080/07055900.1996.9649568.

Corbosiero, K. L., and R. A. Lazear, 2013: Verification of thunderstorm occurrence using the National Lightning Detection Network. Sixth Conf. on the Meteorological Applications of Lightning Data, Austin, TX, Amer. Meteor. Soc., 8.4, https:// ams.confex.com/ams/93Annual/webprogram/Paper221132.html.

Court, A., and J. F. Griffiths, 1986: Thunderstorm climatology. Thunderstorm Morphology and Dynamics, Vol. 2, Thunderstorms: A Social, Scientific, and Technological Documentary, 2nd ed. E. Kessler, Ed., University of Oklahoma Press, 9-39.

Cummins, K. L., and M. J. Murphy, 2009: An overview of lightning locating systems: History, techniques, and data uses, with an in-depth look at the U.S. NLDN. IEEE Trans. Electromagn. Compat., 51, 499-518, https://doi.org/10.1109/ TEMC.2009.2023450.

,-- E. A. Bardo, W. L. Hiscox, R. B. Pyle, and A. E. Pifer, 1998: A combined TOA/MDF technology upgrade of the U.S. National Lightning Detection Network. J. Geophys. Res., 103, 9035-9044, https://doi.org/10.1029/98JD00153.

Earth Systems Research Laboratory, 2019a: Climate timeseriesAMO (Atlantic Multidecadal Oscillation) index. NOAA/ Earth Systems Research Laboratory, accessed 4 March 2019, https://www.esrl.noaa.gov/psd/data/timeseries/ $\mathrm{AMO} /$.

__, 2019b: Multivariate ENSO index version 2 (MEI.v2). NOAA/Earth Systems Research Laboratory, accessed 4 March 2019, https://www.esrl.noaa.gov/psd/enso/mei/.

Easterling, D. R., and P. J. Robinson, 1985: The diurnal variation of thunderstorm activity in the United States. J. Climate Appl. Meteor., 24, 1048-1058, https://doi.org/10.1175/15200450(1985)024<1048:TDVOTA $>2.0$. CO;2.

Environmental Systems Research Institute, 2018: Point Statistics. ArcGIS for Desktop, accessed 12 July 2018, http:// desktop.arcgis.com/en/arcmap/10.3/tools/spatial-analyst-toolbox/ point-statistics.htm.

Fosdick, E. K., and A. I. Watson, 1995: Cloud-to-ground lightning patterns in New Mexico during the summer. Natl. Wea. Dig., 19, 17-24.

Holle, R. L., 2014: Diurnal variations of NLDN-reported cloudto-ground lightning in the United States. Mon. Wea. Rev., 142, 1037-1052, https://doi.org/10.1175/MWR-D-1300121.1

, K. L. Cummins, and W. A. Brooks, 2016: Seasonal, monthly, and weekly distributions of NLDN and GLD360 cloud-toground lightning. Mon. Wea. Rev., 144, 2855-2870, https:// doi.org/10.1175/MWR-D-16-0051.1.

Hu, Q., and S. Feng, 2012: AMO- and ENSO-driven summertime circulation and precipitation variations in North America. J. Climate, 25, 6477-6495, https://doi.org/10.1175/JCLI-D-1100520.1 .

Huffines, G. R., and R. E. Orville, 1999: Lightning ground flash density and thunderstorm duration in the continental United States: 1989-96. J. Appl. Meteor., 38, 1013-1019, https://doi.org/10.1175/1520-0450(1999)038<1013:LGFDAT > 2.0.CO;2.

Koshak, W. J., K. L. Cummins, D. E. Buechler, B. Vant-Hull, R. J. Blakeslee, E. R. Williams, and H. S. Peterson, 2015: Variability of CONUS lightning in 2003-12 and associated impacts. J. Appl. Meteor. Climatol., 54, 15-41, https://doi.org/10.1175/ JAMC-D-14-0072.1.

Krider, E. P., R. C. Noggle, and M. A. Uman, 1976: A gated, wideband magnetic direction finder for lightning return strokes. J. Appl. Meteor., 15, 301-306, https://doi.org/10.1175/ 1520-0450(1976)015<0301:AGWMDF>2.0.CO;2.

Lang, T., and Coauthors, 2017: WMO world record lightning extremes: Longest reported flash distance and longest reported flash duration. Bull. Amer. Meteor. Soc., 98, 1153-1168, https:// doi.org/10.1175/BAMS-D-16-0061.1.

Lopez, R. E., and R. L. Holle, 1986: Diurnal and spatial variability of lightning activity in northeastern Colorado and central Florida during the summer. Mon. Wea. Rev., 114, 1288-1312, https://doi.org/10.1175/1520-0493(1986) $114<1288$ :DASVOL $>2.0$. CO; 2 .

MacGorman, D. R., and W. D. Rust, 1998: The Electrical Nature of Storms. Oxford University Press, $422 \mathrm{pp}$.

- I. R. Apostolakopoulos, N. R. Lund, N. W. S. Demetriades, M. J. Murphy, and P. R. Krehbiel, 2011: The timing of cloud-to-ground lightning relative to total lightning activity. Mon. Wea. Rev., 139, 3871-3886, https:// doi.org/10.1175/MWR-D-11-00047.1.

Mäkelä, A., P. Rossi, and D. M. Schultz, 2011: The daily cloud-toground lightning flash density in the contiguous United States and Finland. Mon. Wea. Rev., 139, 1323-1337, https://doi.org/ 10.1175/2010MWR3517.1.

_ S. E. Enno, and J. Haapalainen, 2014: Nordic Lightning Information System: Thunderstorm climate of northern Europe for the period 2002-2011. Atmos. Res., 139, 46-61, https:// doi.org/10.1016/j.atmosres.2014.01.008.

Medici, G., K. L. Cummins, D. J. Cecil, W. J. Koshak, and S. D. Rudlowsky, 2017: The intracloud lightning fraction in the contiguous United States. Mon. Wea. Rev., 145, 4481-4199, https://doi.org/10.1175/MWR-D-16-0426.1.

Murphy, M. J., and A. Nag, 2015: Cloud lightning performance and climatology of the U.S. based on the upgraded U.S. National Lightning Detection Network. Seventh Conf. on the Meteorological Applications of Lightning Data, Phoenix, 
AZ, Amer. Meteor. Soc., 8.2, https://ams.confex.com/ams/ 95Annual/webprogram/Paper262391.html.

National Climatic Data Center, 2019a: Pacific Decadal Oscillation (PDO). NOAA/National Centers for Environmental Information, accessed 4 March 2019, https:// www.ncdc.noaa.gov/teleconnections/pdo/.

__, 2019b: Southern Oscillation Index (SOI). NOAA/National Centers for Environmental Information, accessed 4 March 2019, https://www.ncdc.noaa.gov/teleconnections/enso/ indicators/soi/.

National Weather Service, 1998: Automated Surface Observing Systems (ASOS) user's guide. NOAA, 65 pp., https:// www.weather.gov/media/asos/aum-toc.pdf.

_ 2018: 79-year list of severe weather fatalities. NOAA, 1 pp., https://www.weather.gov/media/hazstat/79years.pdf.

Orville, R. E., 1991: Lightning ground flash density in the contiguous United States-1989. Mon. Wea. Rev., 119, 573-577, https:// doi.org/10.1175/1520-0493(1991)119<0573:LGFDIT>2.0.CO;2. 2008: Development of the National Lightning Detection Network. Bull. Amer. Meteor. Soc., 89, 180-190, https:// doi.org/10.1175/BAMS-89-2-180.

, and G. R. Huffines, 2001: Cloud-to-ground lightning in the United States: NLDN results in the first decade, 1989- 98. Mon. Wea. Rev., 129, 1179-1193, https://doi.org/10.1175/15200493(2001)129<1179:CTGLIT>2.0.CO;2.

Reap, R. M., 1986: Evaluation of cloud-to-ground lightning data from the western United States for the 1983-84 summer seasons. J. Climate Appl. Meteor., 25, 785-799, https://doi.org/ 10.1175/1520-0450(1986)025<0785:EOCTGL > 2.0.CO;2.

, and R. E. Orville, 1990: The relationships between network lightning locations and surface hourly observations of thunderstorms. Mon. Wea. Rev., 118, 94-108, https://doi.org/ 10.1175/1520-0493(1990)118<0094:TRBNLS > 2.0.CO;2.
Roeder, W. P., B. H. Cummins, K. L. Cummins, R. L. Holle, and W. S. Ashley, 2015: Lightning fatality risk map of the contiguous United States. Nat. Hazards, 79, 1681-1692, https:// doi.org/10.1007/s11069-015-1920-6.

Taszarek, M., B. Czernecki, and A. Kozioł, 2015: A cloudto-ground lightning climatology for Poland. Mon. Wea. Rev., 143, 4285-4304, https://doi.org/10.1175/MWR-D15-0206.1.

U.S. Department of Commerce, 2017: Surface weather observations and reports. Federal Meteorological Handbook, No. 1, Tech. Doc. FCM-H1-2017, NOAA/National Weather Service, 98 pp., https://www.ofcm.gov/publications/ fmh/FMH1/FMH1_2017.pdf.

U.S. Naval Observatory, 2012: Approximate solar coordinates. U.S. Naval Observatory, accessed 8 December 2015, https://www.usno.navy.mil/USNO/astronomical-applications/ astronomical-information-center/approx-solar.

Wallace, J. M., 1975: Diurnal variations in precipitation and thunderstorms over the conterminous United States. Mon. Wea. Rev., 103, 406-419, https://doi.org/10.1175/15200493(1975)103<0406:DVIPAT>2.0.CO;2.

Watson, A. I., and R. L. Holle, 1996: An eight-year lightning climatology of the southeast United States prepared for the 1996 Summer Olympics. Bull. Amer. Meteor. Soc., 77 883-890, https://doi.org/10.1175/1520-0477(1996)077<0883: AEYLCO $>2.0 . \mathrm{CO} ; 2$.

World Meteorological Organization, 1953: World distribution of TDs. WMO Rep. 21, TP. 6, WMO, Geneva, Switzerland, $204 \mathrm{pp}$.

Zajac, B. A., and S. A. Rutledge, 2001: Cloud-to-ground lightning activity in the contiguous United States from 1995 to 1999. Mon. Wea. Rev., 129, 999-1019, https://doi.org/10.1175/15200493(2001)129<0999:CTGLAI > 2.0.CO;2. 